\title{
Diplomatičke isprave Općine Lokva Rogoznica
}

\author{
Bartul Marušlć \\ Libertas međunarodno sveučilište \\ E-pošta:mlmarusi@inet.hr
}

\author{
UDK: 94(497.5 Lokva Rogoznica)"04/14" \\ 352(497.5 Lokva Rogoznica)"04/14 \\ Pregledni rad \\ Primljeno: 10. veljače 2019. \\ Prihvaćeno: 21. svibnja 2019.
}

\section{Sažetak}

Lokva Rogoznica u srednjoj Dalmaciji, od svojega osnutka početkom 13. pa sve do početka 19. stoljeća, bila je samostalna općina. Ta je općina od svojega nastajanja sve do venecijanske vlasti imala obilježja plemićke, a u promatranom razdoblju evoluirala je čak do statusa polusuverene republike pod patronatom. To mjesto, iako je manje od susjedne kneževine Poljica i grada Omiša, te je prečesto zanemarivano u pravnoj i općoj historiografiji, imalo je itekako važan utjecaj na povijest priobalnoga teritorija od Omiša do Makarske. A on je učestalo bio granica između istočnoga, islamskoga i zapadnoga, kršćanskoga vladanja. U tim previranjima kroz ratove Lokva Rogoznica sklapala je mnoge važne pravno-povijesne i međunarodne ugovore s Mletačkom Republikom koji su joj određivali budući položaj i koji je još poduprt mnogim dukalima o potvrdi plemićkih privilegija i statusa. Imala je jednu od vodećih i ključnih uloga u politici primorja prema Osmanlijama, Veneciji i ostalim silama. Ipak, njezin najvažniji dokument jest Statut u dva dijela, napisan 1235. i 1236. On je jedan od najstarijih dalmatinskih zakona u razvijenome srednjem vijeku i na samom je začetku dalmatinskoga statutarnoga prava. Nakon bogate povijesti Rogoznica je opstala unatoč svim izazovima i u posljednjim dvama stoljećima uključena je u Omišku općinu i 
Republiku Hrvatsku. U radu se govori o povijesnoj kronologiji i o važnim pravnim dokumentima te se najvažnije diplomatičke isprave prvi put objavljuju na jednome mjestu.

Ključne riječi: Lokva Rogoznica u srednjem vijeku i Hercegovačkom sandžaku; primorske plemićke općine; povijest i pravo srednje Dalmacije; Rogoznički statuti.

\section{Uvod}

Današnja je Lokva Rogoznica mjesto koje se nalazi u omiškoj općini u srednjoj Dalmaciji. Ima svoju župu u koju su uključena ostala manja okolna mjesta (Marušići, Mimice, Pisak, Stanići, Medići...) koja su se mahom kao sateliti proširila prvotno od nje same. Sva ta mjesta na čelu s njom u središtu protežu se od Omiša do Vruje, iza koje počinju Makarska rivijera i primorje, a poviše, između mosorskih obronaka i Biokova, počinje i penje se kroz Dupce Općina Žeževica i Zadvarje koje vodi u zaleđe prema Šestanovcu, Imotskom itd. Povijest Rogoznice počinje s 13. stoljećem i uglavnom je spominjana u sklopu opće dalmatinske ili omiške povijesti ili u fragmentarnim radovima na razne teme. Međutim, jedna kompilacija koja bi se ticala njezine opće te pravne povijesti, u smislu važnih javnopravnih i međunarodnih odnosa i dokumenata zajedno s njihovom interpretacijom te najvažnije interne zakonske uredbe - Rogozničkoga statuta, nije napravljena. Jedini koji si je dao oduška i napravio zadovoljavajuću analizu prvih rogozničkih zakona (ali bez onoga iz 1236.) jest dr. Miroslav Pera u Zborniku Pravnog fakulteta u Splitu 1984., ali uz dosta nedorečenosti i manjak kvalitetne komparativne analize statutâ toga kraja općenito. Rogoznica je podosta zanemarena, premda je više nego važna za dugačko područje između Omiša i Makarske, a i za cijelu srednju Dalmaciju uopće. Da ne zvuči pretenciozno, od važnosti je i za hrvatsku pravnu povijest jer se njezin statut, šire prihvaćeno, svrstava u najuži krug prvih statuta u Dalmaciji i u začetke statutarnoga prava globalno. Pera se čak priklanja tezi i sumnji kako je datacija Korčulanskoga statuta sumnjiva i kako je Rogoznički iz 1235. naš najstariji statut ${ }^{1}$ (kojemu se nije posvetila ozbilina pozornost). Iako se

1 Statut je otisnut (ali u prijepisu i na starotalijanskom) u listu La Dalmazia, 22/1845., a nalazi se u Bogišićevim spisima u naučnom arhivu u Cavtatu, kut. IV., 31-33, rukopisi 1867. (11. 7. 2016.) i Državnom arhivu u Zadru HRDAZD-33 Vlada za Dalmaciju, 1802., sv. 167; br. spisa 852, str. 1/264-266. (6. 7. 2016.). 
još otkrivaju i novi izvori (Nin...). Doduše, najstariji sačuvani izvornik Korčulanskoga statuta, onaj iz 1265., nigdje ne spominje 1214. godinu kao izvorišnu, nego tek kasnije redakcije. Svejedno, Šuflay, Wenzel, Reutz i općenito povjesničari uzimaju taj datum kao točan. Iako kratak, ${ }^{2}$ poput Korčulanskoga, rogoznički zakonik odražava prilike toga doba i važnost hrvatskoga plemstva za očuvanje postojanosti u državnim zajednicama koje su počele s ugarskom unijom. Lokva Rogoznica kroza srednji vijek bila je plemićka općina, a poslije i republika pod patronatom, odnosno protektorat. ${ }^{3} \mathrm{Uz}$ Poljica, kao uvijek granično priobalno područje, imala je ključnu ulogu za povijest toga današnjeg dijela Hrvatske u previranjima između mletačkih, gusarskih, osmanlijskih, francuskih, austrijskih i drugih presezanja i "okupacija". Dovoljno je impozantan i nedovoljno poznat njezin pozitivan i tolerantan odnos s gotovo svim uređenjima i vladarima tako da se greška zanemarivanja uloge Rogoznice (i u pravu i u historiografiji) treba što prije ispraviti. Pokušat ćemo to učiniti u ovom radu, ponajprije uvodnom kronologijom najbitnijih događaja i isprava važnih za taj kraj. Da bismo imali cjelokupan zanimljiv uvid, bilo je potrebno posegnuti za izvorima na raznim jezicima kao što su (staro)hrvatski, ${ }^{4}$ a još više (staro)talijanski, ${ }^{5}$ latinski, ${ }^{6}$ engleski, njemački, ${ }^{8}$ francuski i mađarski, ${ }^{9}$ te pismima poput (staro)latinice te hrvatske (bosančice) i srpske ćirilice. Literaturu zato čine knjige i članci, ali i diplomatički zbornici i arhivska građa (Zagreb, Zadar, Cavtat, Split).

Odvjetnik dr. Miroslav Pera u "Prvim rogozničkim zakonima" osvrće se na uvodnik i talijanski prijevod Rogozničkoga statuta koji se može

2 "S iznimkom dubrovačkih odredaba o kaznenom pravu, čini se da su u to doba bili ipak kratki propisi, sačuvani na jednom listu pergamene", Nella LonZA, "Pravna kultura srednjovjekovne Dalmacije između usmenosti i pismenosti", u: Zbornik Pravnog fakulteta u Zagrebu, vol. 63, No. 5-6, 2013., str. 1223.

3 "Revue droit international - legislation comparee", Tome XXV., No. 1, 1893. str. 466-477. Tu su i stajališta veleposlanika Engelhardta.

4 Za potrebe ovoga rada prijevod - Ivan Kosić.

5 Prijevod - autor, Dijana Brezak, Dražena M. i prije prof. Vladimir Rismondo. Pravni su dijelovi i u drugom radu vezano za raspravu oko dodjele plemstva i ukidanja protektorata.

6 Prijevod autora i Tajane Ćipurić-Furdek.

7 Prijevod autora.

8 Prijevod Ante Marušić.

9 Prijevod Lea Kovacz. 
vidjeti na prvim stranicama eminentnoga zadarskog časopisa "La Dalmazia", br. 22 iz rujna 1845. Uvodnik je napisao Giovanni (Ivan) Franceschi koji je do statuta prvi i javno došao. Pera, dobar pravni stručnjak, pokatkad malo previše ambiciozno, široko i na granici diletantizma ulazi u povijesni ${ }^{10}$ i filozofski kontekst statuta, pa tako i Rogozničkoga. Piše o pojmovima depersonalizacije, transpersonalizacije, voluntarizma, fatalizma, nasilja i dominacije te božanskoga prava općenito za to razdoblje. Stoga njegov uvod ne daje mnogo uvida u prilike same Rogoznice niti se trudi u to ulaziti. Poslije se upušta u osnovnu interpretaciju (bez komparacije) statuta o kojemu sada ne ćemo govoriti, a povijesni okvir i položaj Rogoznice kroz povijest ne spominje. A to ne čini nijedan drugi autor na jednome mjestu.

Pokušat ćemo dakle upozoriti na najvažnija i ključna razdoblja, pravne dokumente i događaje u povijesno-pravnom kontekstu vezane za taj kraj i prilike općenito.

\section{Migracije plemstva}

Godine 1231., u vrijeme vladavine Andrije II., sedam plemićkih obitelji (Davidović, Dikličić, Rubnić, Vojnić, Mikulić, Radić i Blažević) otišlo je iz svoje izvorne sjeverne postojbine i migriralo na jadranski jug. ${ }^{11}$ Ondje su naselile visoki i brdoviti kraj istočno od Omiša, koji je bio nepristupačan, ali povoljan za obranu, bijeg i općenito život nakon eventualne egzistencijalne konsolidacije i stvaranja obradivih polja. Smjestili su se u kraju blizu mora s dostupnom pitkom vodom, a opet na visokoj nadmorskoj visini koja im je pružala položaj s kojega su imali odličan pregled, poput tvrđave Fortice ili Mirabele u Omišu, i kontrolu svega i svih koji su dolazili s mora ili iz planinskoga zaleđa. Planinske pukotine, divlji putovi, šuma i špilje jamčili su im brz i kratak eventualni bijeg od neprijatelja i povratak na ognjišta. Glavna opasnost toga doba zasigurno je bila gusarstvo i ona je uvelike uklonjena zbog najvišega okolnog položaja na mjestu zvanom Gorica na kojemu je i počeo život. Dandanas se na vrhu planine nalazi malena crkva (sv. Vida - sve vidi) na tada najvećoj nadmorskoj visini. Crkvica je renovirana (helikopterom) tijekom devedesetih godina prošloga stoljeća, a datira upravo iz 13.-14. stoljeća. Sagrađena je prije

10 Neven Budak, kritička recenzija knjige Poljički statut, vrlo negativna prema povijesnim tezama u njoj.

11 La Dalmazia, op. cit., i HR-DAZD 33, op. cit. 
glavne, župne crkve Uznesenja Blažene Djevice Marije čija je gradnja bila propisana već 1235. u Statutu. Njega su donijeli, piše, 4 godine nakon dolaska kako bi po njemu i vladali. "Aneks" je nastao godinu dana poslije, početkom $1236 .{ }^{12}$

Glavno "prethodno" pitanje jest kakvo je plemstvo bilo i zašto je migriralo. ${ }^{13}$ Migracije su u srednjem vijeku bile česte, iako su kolektivne, što se tiče plemstva, zabilježene tek kasnijim, osmanlijskim osvajanjima, i to prema zapadu i sjeveru. Plemićke su obitelji pripadale rodu Ugričića i dolazile su iz (Hrvatsko-)Ugarske, a zanimljivo je da su poljički Ugričići, prema predaji, također kao "vlastela" došli gotovo stoljeće kasnije u Poljica i nametnuli se lokalnim plemićima "didićima", što bi pak bilo nakon najezde Tatara. U Omišu se dakako nalazilo autohtono hrvatsko "pleme" Kačići koji su slovili za najopasnije gusare i vladare kopna i mora (i otoka) u tom dijelu. I zato se najčešće u arhivima i Codexu Diplomaticusu spominju u 13. stoljeću. ${ }^{14}$ Možda je radi pariranja njima kralj upravo poslao naše plemiće na jug, iako to djeluje riskantno. S druge strane, pitanje je kako bi i zašto bez kraljeva dopuštenja ili naredbe takve obitelji išle toliko daleko, osim ako nije bila riječ o progonima. Neki misle da su Rogozničani hrvatsko rodovsko plemstvo (prof. dr. Slavko Kovačić), ${ }^{15}$ dok drugi pretendi-

12 Objavljen je u broju 19. časopisa "Hercegovina", 3/2017.

13 Najčešće teorije vežu se uz progon od Tatara, no to ostavlja sumnju jer u to doba Tatari tek da su počeli djelovati u Aziji pa u Rusiji od 1236. do 1240. i potom u istočnoj Europi (Ukrajini), a zna se da se njihov glavni prodor $u$ Ugarsko kraljevstvo (nakon Poljskoga), koji je uzrokovao pad i bijeg Bele IV. na jug, dogodio tek 1242. nakon bitke na rijeci Šajo i pogibije Belina sina Kolomana od zadobivenih rana (dok se ova migracija dogodila još za života oca Andrije II.) Kako god, obitelji su se nastanile i otpočele dug i ne uvijek lagan životni put. (O Tatarima usp.: Peter F. Sugar, A history of Hungary, Indiana University Press, 1944., str. 24 i dalje.)

14 "Andrija prijeti svom silinom Kačićima ako ne odustanu od gusarstva", "Savez kralja napuljskog Karla III. sa Splitom i Šibenikom protiv Omiša", "Omišani porobili brod (križarski koji je sam bio pljačkaški) i za Ugarsku", "Omišani pokrali biskupa Kefalonije", "Pogodba između Trogirana i Omišana... mir Omiša i Dubrovnika... ugarski kralj se žali papi Piu...", Codex Diplomaticus (dalje: CD), sv. 3 (162), 4, 5, 6, 7 (174), JAZU, Tadija Smičiklas (prir.), 1905.

15 Dalje se spominje u tekstu. I Ante conte Duišin u "Zborniku plemstva" Davidoviće-Marušiće stavlja u kontekst hrvatskoga praplemstva, što, kao ni većinu, nije potkrijepio izvorom. I on opet ponavlja da su bježali od Tatara u 13 . stoljeću, što je prijeporno, jer je građanskih sukoba bilo prije, kako primjećujem da piše i Alačević u Bogišićevu arhivu vezano za rogozničku povijest. 
raju na to da su ipak kraljevsko ${ }^{16}$ serviens regis - ugarska vlastela "vlastelinčići" (prof. dr. Ante Marušić i M. Pera) koje je plemstvo i dobilo europski zamah upravo u doba vladavine Andrije II. (što mu je i sin Bela zamjerio). Nemoguće je apsolutno se prikloniti samo jednomu bez dokaza, ali, ako su rodovsko plemstvo, ne zna se njihovo podrijetlo jer ne pripadaju jasno dvanaesterim plemenima Kraljevine Hrvatske (koja su navodno sklopila Pactu Conventu s kraljem Kolomanom 1102.). S druge strane, kraljevskoga je plemstva bilo relativno mnogo i neimenovanoga u dokumentima koji su možda i propali uvelike zbog najezde Tatara, Turaka i drugih kasnijih osvajača. I, ako ipak prihvatimo tu, potonju pretpostavku, može se zaključiti da su zemlju u Rogoznici dobili kao darovanu kraljevskom darovnicom ili makar plemstvo kao takvo. To se spominje i u kasnijim potvrdama pa bih se i ja složio s tvrdnjom da su ipak kraljevski plemići ("sluge" i po zasluzi). I morali su imati neki pisani legitimitet za budućnost, samo se ne zna kakav. Oni kao donacionalno i masovno plemstvo vlastele itekako imaju snagu, ali svejedno su podalje od cetinskih knezova. Zbunjuje samo činjenica da se ni kralj ni darovnica ne spominju u uvodnome dijelu Statuta, ali to možda više zbog želje za vlastitom emancipacijom i neprenaglašavanjem odanosti kralju koji je već uvelike udaljen od njih i njihovih problema i kontrole (iako je bio formalni vladar ovih krajeva). Pozivanje na kraljevstvo trebalo im je pak radi buduće legitimacije. Miroslav Pera ide do toga da proglašava kako su oni tu zemlju originarno (i slučajno) stekli i zatekli. I to "drži vodu" ako su pobjegli zbog internih ili vanjskih sukoba, a u svakome drugom slučaju, kao takvi, imali su ili morali imati odnos i dogovor s kraljem. Taj se odnos manifestirao kroz stvaranje saveza nižega plemstva protiv velikaša, a i kralja, i koji je prisilio Andriju II. na donošenje velike Zlatne bule 1222. U njoj je on dopustio mnoge privilegije širokom plemstvu, iako ih je poslije pokatkad i kršio. Neke su od njih bile, a implementirane su i u kasniju statutarnu svijest, da se plemići ne smiju zatvarati bez velikog suda, ne smiju plaćati poreze i namete niti potpadati pod sudbenost župana, a u vezi s vojnim obvezama kralju ${ }^{17}$ bili su se dužni odazvati u defenzivnom ratu be-

16 Iako kralja, primijetit će i Pera, poimence ne spominju i marginaliziraju time njegovu supremaciju i superiornost i potiskuju superordiniranost Ugarske kao takve, ipak im ona služi kao izvorni legitimitet za buduću društvenu reputaciju i položaj.

17 Niži su plemići morali pojedinačno u rat, a veći su odbijali i ići u njega. Nobilitet je ipak vezan za osobu, a ne za posjed stečen kraljevim darovnicama 
splatno, a u navalnim ratovima na njegov trošak. Ni kraljevi konjušnici, pisari i ostali nisu se smjeli usuditi zalaziti u plemićka selišta. Nisu bili dužni plaćati ni desetinu u srebru, nego u vinu (kao i kasnije Mletcima sl.), a na pašu im nisu smjele dolaziti svinje, pa ni kraljevske. Jamčile su se sloboštine sv. kralja Stjepana, a najvažniji od svih privilegija i presedan bio je jus resistendi koji je plemićima davao pravo na otpor, pa i vlastitu kralju, odnosno njegovim sljednicima. Ta je bula uvelike nalik na Magnu Cartu Libertatum i kraljevo upletanje u plemićke posjede bilo je ograničeno kako ne bi mogao dvaput darovati istu zemlju. Servientes regis prvi se put spominje u povelji iz 1217. godine ${ }^{18}$ a samom bulom, iako se ona prije svega odnosi na sve plemiće, poslije su od "kraljevih slugu" stvoreni sloj i baza "nižega" plemstva. ${ }^{19}$ Takvo je plemstvo bilo u oprjeci s velikašima koji, iako su pravno izjednačeni, ipak su bogatstvom i moći prevladavali. Kralju je odgovarao paritet. S druge strane, u vrijeme Ludovika Anžuvinca niže se plemstvo u interesima ponovno ujedinilo s višim kako bi branilo consuetudines Croatorum. Godine 1231., upravo u vrijeme seobe, bula je dobila dodatak. Pitanje je i koji je kralj, ako jest, dodijelio plemstvo ili imanje (dakle kada). Pera odmah ispravlja Franceschog i slične koji kažu da su se doseljenje te dobivanje povlastica i darovnice dogodili u doba Bele IV. jer je 1231., po svemu sudeći, još vladao Andrija II. koji je i dao zamah takvom plemstvu pa je i najrealnije da je

kojima nema traga poslije 1102. A i porez je Ludovik svim plemićima, osim dvanaestorici, počeo nametati kao marturinu. Barada pak smatra da pravo hrvatsko plemstvo i seže tek od Kolomanovih darovnica, a ne od doseljenja.

Vidjeti opširnije: NAdA KlaIĆ, "Plemstvo dvanaestero plemena Kraljevine Hrvatske", u: Historijski zbornik, god. IX., br. 1-4, 1956., str. 83-100.

18 O tome Martyn Rady, Nobility, Land and Service, Palgrave Macmillan, 2000.

19 "Počevši od II. pol. 13. st., pripadnici plemstva po statusu iza baruna te uski krug svj. dostojanstvenika i istaknutih plemićkih obitelji, zajedno sa... servientis regis, počeli su se organizirati u jedinstveno plemstvo... Na njihovoj skupštini održanoj u Ostrogonu 1267. godine, ti plemići u svojoj su peticiji zahtijevali pravo na raspolaganje imovinom, ograničeno pravom srodnika", Gábor BéLi - Marko Petrak - Igor Gliha, "Utjecaj rimskog i drugih stranih pravnih sustava na ugarsko-hrvatsko pravo u razdoblju do 1848. godine", u: Suvremeni pravni izazovi Eu-Mađ-Hrv, Pečuh - Osijek, 2012., str. 62.

Rogozničko plemstvo očito nije imalo potrebe ni mogućnosti poslije ulaziti u plemićka vijeća u drugim okolnim gradovima, jer su, kao prvo, bili autonomni a, kao drugo, zbog opasnosti i konkurencije, jer plemići u jednom gradu nisu morali imati isti status u drugom. Neki su zato u sjevernim manjim primorskim krajevima stjecali plemstvo kako bi njime pokušali biti priznati i u (drugim) gradovima. Ali proces je, iako moguć, bio mnogo sporiji. 
to bio on (tako tvrdi i Ante Marušić). Opet brzopleto, ni Pera ne može biti siguran u to jer nije ostavio mogućnost da su u to isto vrijeme akt mogli učiniti i on i sinovi mu Bela i Koloman! Zato što su obojica vladala Hrvatskom kao mlađi kraljevi i hrvatski hercezi (tzv. rex junior), i to prvi do oko 1225., a drugi od tada pa sve do smrti zbog tatarskoga ranjavanja 1242 . Oni su imali punu upravnu vlast nad hrvatskim herceštvom i upravo mogli dodjeljivati i plemićke povlastice. No dokumenti su i tu šturi. ${ }^{20}$ Prije svega, pleme se uzima kao najširi pojam zajednice, ali se često i djelomično pogrešno izjednačuje s plemenitošću kao staleškom i društvenom vrlinom i položajem. ("Izvori pisani hrvatskim jezikom uvijek koriste riječ pleme za označavanje plemićkog stanja.") ${ }^{21}$ Dalje slijedi rod, ${ }^{22}$ pravno, genus (ali uglavnom ne kao agnatske obitelji u koju se ubrajaju samo muški potomci akka styrps) te u konačnici obitelj (njih sedam u Rogoznici).

20 "Najvažniji razvoj u tom razdoblju bilo je isticanje plemstva i kao klase i kao političke snage. U Ugarskoj 'plemstvo' nije označivalo isti socijalni fenomen kao drugdje. U većini europskih država klasa plemića izrasla je od vitezova i bila aristokracija odvojena od ostalih po rođenju i moći s drukčijim životnim stilom kojim su 'živjeli' plemenito. Mađarsko se plemstvo etabliralo kao klasa tijekom 13. st., i to na drugi način. I bilo je oštro osvojeno od puka. Vjerojatno mnogo više nego drugdje, ali ključ te separacije bili su alodijalna priroda imovine i privilegiji koji su bili pridodani ( ${ }^{*}$ iako se katkad to događalo i zbog vojnih ili drugih zasluga, baš nakon Tatara, recimo). Zbog toga su mnogi, koji bi u drugom dijelu Europe bili smatrani plebejcima, u Ugarskoj bili plemići. Glavno je bilo to što su jedni radili na svojoj zemlji, a drugi na tuđoj... Velika razlika između slobodnih i serva bila je zamijenjena distinkcijom na one koji su radili i one koji su išli u rat. Kraljevi plemići u doba Andrije II. bili su i oni dosta siromašni, a status su dobivali plemićkom poveljom. I oni su se u traženju prava homogenizirali s većim plemićima kao 1222. U Hontu je npr. bilo najmanje 40 plemićkih naseobina, a u Bihoru i stotine. Status kraljevih plemića sličan je i anglosaksonskim koji su također služili izravno kralju. Ali malo se zna o njima, iako je takav bio taj široki fenomen u 13. st...." Pál EngEL, The realm of st. Stephen, A History of Medieval Hungary, 895-1526., I. b. Tauris, 2005., str. 83.

21 Damir Karbić, "Hrvatski plemićki rod i običajno pravo", u: Zbornik Odsjeka za povijesne znanosti zavoda HAZU, 16, Zagreb, 1998., str. 73.

22 "Rod je oblik obiteljske strukture koji se temelji na stvarnom ili izmišljenom podrijetlu od zajedničkog pretka čiji članovi posjeduju neku imovinu i žive u zajedničkom domaćinstvu. To je oblik proširene obitelji koja sadrži više pobočnih generacija..." "Imovina roda se sastojala od patrimonijalnog posjeda i stečene imovine." D. Karbić, "Hrvatski plemićki rod i običajno pravo", str. 73, 111. U Poljičkoj se republici patrimonijalni posjed terminološki izjednačivao i nazivao - plemenščinom. 
Obitelj Marušića-Davidovića navodno pripada rodu Oblačići, a već između 13. i 15. stoljeća rodovski sustav organiziranja zamijenjen je i dopunjen teritorijalnim načelom utjelovljenim u plemićkim općinama poput ove, te ostalim teritorijalnim asocijacijama kao što su plemićke župe. ${ }^{23}$ Rodovi su se raspali na manje jedinice obitelji, a "nema ipak mnogo izravnih podataka o tipu obitelji dalmatinskog gradskog plemstva, jednostavnog ili složenog tipa". ${ }^{24}$ Poznato je, ponavljamo, da su originalne povelje o darovnici plemstva, ako su i postojale (i to napismeno) ili uništene ili propale pa ih je teško naći i u mađarskom arhivu u Budimpešti. Stoga ostaju njihove kasnije potvrde. ${ }^{25} \mathrm{I}$ u Dalmaciji i u srcu Hrvatsko-Ugarske još uvijek je pretezala kultura usmenosti. ${ }^{26} \mathrm{U}$ srednjoj Europi (Poljsko kraljevstvo), kod zapadnih Kelta i u Španjolskoj pa i u našemu kraljevstvu u personalnoj uniji s Ugarskom broj plemića bio je očito izrazito veći negoli je to bilo uobičajeno u ostalim europskim zemljama. Udio u ukupnome stanovništvu bio je od 1 do 5 pa čak i do $10 \% .{ }^{27}$ Zato su se te zemlje zvale

23 Damir Karbić, "Plemstvo - definicija, vrste, uloga", u: Povijesni prilozi, 31, Zagreb, 2006., str. 11-21 (20).

24 "...Čini se da je pojedinac iz plemenite dalmatinske obitelji mogao iskusiti nekoliko tipova obiteljskih jedinica tijekom svojeg života: život u jednostavnoj obitelji ili u složenoj koja je mogla biti zajednica oca i sinova ili zajednica braće" (a vjerujem, očito, da je bilo i primitivnijih miješanih i širih rođaka u velikim kućanstvima, što kasnije vidimo i prema popisu). ZRINKA Nikolić Jakus, "Obitelj dalmatinskog plemstva od 12. - 14. stoljeća", u: Acta Histriae, 1-2, 2008., str. 73.

25 Tako i "Bojničić kod svih obrađenih obitelji kalničkog plemstva kao godinu davanja povlastica navodi 1250., iako za to nema nikakvih pisanih dokaza, niti se kakva plemićka diploma igdje spominje... Pozabavimo se prvo nepostojanjem ikakva pisanog izvora o donaciji plemstva. Naime, u Belino vrijeme nije neuobičajeno da se plemstvo dodjeljuje usmenim putem, to je više pravilo nego iznimka." Ozren Blagec, "Bela IV. i Kalničko plemstvo", u: Cris, god. XII., br. 1/2010., str. 236.

Tako je i s turopoljskim plemstvom koje se čak rano spominje, ali isto tek u prepisci za Matijaša Korvina. Glede Rogoznice, Statut, iako se ne zna gdje je završio izvornik, uvelike olakšava i potvrđuje mnoge plemićke potvrde i teze o doseljenju u 13. stoljeću. I okolnosti pod kojima se to dogodilo.

26 "Unatoč tome što su franačko, langobardsko i bizantsko pravo na područjima na kojima su se prostirali u manjoj ili većoj mjeri promovirali pisane oblike, ipak je kroz dugo razdoblje pretežit oblik pravne komunikacije bio usmen i ritualan... Pravni je život moguće pratiti samo kroz blijede tragove u izvorima, ponekad i naknadno sročenima." N. LonzA, "Pravna kultura srednjovjekovne Dalmacije između usmenosti i pismenosti", str. 1206.

27 D. KARBIĆ, "Hrvatski plemićki rod i običajno pravo", str. 73. 
"zemlje brojnog plemstva". Rogozničani kao kraljevo i niže plemstvo imali su postojan status, za razliku npr. od tvrđavnih jobagiona ( $j o-$ bagiones castri) koji su se nazivali i gradokmetovima (uz kmeću dit) te su kao vezani za utvrdu i posjed mogli dobivati plemstvo "ni iz čega", odnosno od običnog građanstva, a isto su ga tako zato mogli više puta ponovno i izgubiti. Međutim, rogoznički su plemići tijekom duge povijesti morali i formalno potvrđivati plemićke povlastice, što su mnogo puta i uspjeli za gotovo svake vlasti (u vrijeme mletačke i češće). Načinom života morali su izboriti nepokorenost da potencijalno ne padnu u niže sfere i okolne županije i općine. To su uspijevali vještom mudrošću i političkom diplomacijom te, nešto rjeđe, vojnim pothvatom. Što se tiče bogatstva, izuzevši krize o kojima će biti riječi, Rogoznica je ipak postala mjesto s velikom vinogradskom i poljoprivrednom plantažom i mogla je sama sebe uzdržavati, što je naglasio i primijetio i Ivan Franceschi. Lokva Rogoznica najvjerojatnije je dobila ime, odnosno dali su joj ga doseljenici, po okolišu jer se i dandanas na Gorici nalazi velika lokva oko koje je morala rasti biljka rogoz, koja uspijeva samo u vlažnom i močvarnom području (Typha latipholia). Odakle su se točno doselili, enigma je koja nije još razjašnjena, a teško je i da može biti. Postoje samo nagađanja. M. Pera i G. Franceschi (i Ante Marušić u "Rodoslovlju obitelji Lovre Bartulova") zaključuju da je morala biti riječ o sjevernoj Hrvatskoj jer imaju hrvatska prezimena (izuzev univerzalnih imena poput Mikloša, Davida, Matiasa). A i pisci Statuta, kao i naknadni vladari, ističu kako im prvotna postojbina i plemstvo seže iz Ugarskoga kraljevstva. Može se prihvatiti kako se to odnosilo na cijelo Hrvatsko-Ugarsko kraljevstvo kao zajedničku državu. Stoga, iako se ne zna točna lokacija, manje je vjerojatno da su se nalazili na jugu današnje Mađarske, a pisci zaključuju da im je prebivalište prije moglo bili na južnim granicama Hrvatske s (današnjom) Bosnom. Budući da su putem kroz Bosnu pokupili 10 novih pastira kao kmetove, što i sami ističu, to djeluje realno, ali je pogrješno time implicitno zaključiti kako to znači da su iz same Bosne i krenuli. S jedne strane, zato što su naglasili da su kroz Bosnu "proputovali", a, s druge strane, postavlja se bitno pitanje obuhvaća li ta "Bosna" uopće granice današnje ili tadašnje $\mathrm{BiH}$ i iz koje perspektive mi to želimo gledati. Ako gledamo s tadašnje, još je manja šansa da su krenuli iz Bosne jer tada je ona bila manja i uvučenija, a, ako je točno da su došli 1231., četiri godine prije donošenja zakona, onda je to bilo upravo u doba smjene bana Stjepana Matejem Ninoslavom na vlasti u Bosni, gdje je, u usporedbi s Ugarskom, bilo nesigurno za bilo kakav prolazak. Bosna se otada 
počela postupno širiti. Pitanje je kako su sami znali da prolaze kroz nju i jedino gdje su je morali sigurno presjeći jest južni dio koji je bio i ostao iza zaleđa Dalmatinske zagore, oko Ključa i Glamoča. Mogu navesti samo neprovjerene ideje oko podrijetla ako pristanemo uz hipotezu da su ime već "prenijeli" otprije. Zanimljivo je da rijeku, odnosno potok Rogoznu, Bela IV. često spominje (u sv. IV. CD-a), a ona se nalazi(la) u blizini Čazme. Isto tako u Gorskom kotaru postoji mjesto Lokve i blizu njega planinski vrh Rogozno. Stoga bi kao umanjenica od toga dvojega mogla biti - L. Rogoznica. Ali u tom slučaju ne bi bilo potrebe sjeći Bosnu te bih (zasad) odbacio tu teoriju jer bi i logičnije bilo da su u tom slučaju mjestu, jednostavno, dali ime - Lokva Rogozna. Ključno za razumijevanje jest kardinalno razlikovanje (današnje omiške) Lokve Rogoznice koja se u izvorima navodi samo kao Rogoznizza, Rogosniza ili slično, za razliku od (šibenske) Rogoznice. Potonja se kao uvala u povijesti tek nešto češće spominje $\mathrm{u}$ vezi s pomorskim gusarskim borbama s engleskom flotom i francuskom upravom tijekom njezina osvajanja. Također, samo su rogozničke obitelji bile plemenitaške i samo prezimena koja svoj izvor crpe s toga područja imala su taj status i titulu bez obzira na to što istih prezimena ima i u susjednim krajevima, ali drukčijega etimološkog i stvarnog podrijetla i genealogije. Rogoznica (op. Lokva) prvi put se spominje u najstarijemu pronađenom izvoru i dokumentu na hrvatskoj ćirilici, odnosno bosančici - Povaljskoj listini za koju se uzima da datira iz 1250. godine (kao svoja druga inačica) i koja je pronađena sasvim slučajno u polju na Braču. Danas se ona čuva $u$ Pučišćima u župnom uredu na najvećem dalmatinskom otoku. Upravo se za Brač i Pučišća veže i uža povijest rogozničkih Marušića od odseljenja, tj. doseljenja Matije Davidovića (Marušića) s obitelji. Tu se u župnim knjigama vodio kao (pl.) plemenit te je odigrao bitnu ulogu za mjesto i župu kada je gradio kulu i ostao upisan u nju inicijalima M. D. koji podsjećaju i na ime samoga nestora i rodonačelnika prvih Davidovića u Rogoznici - Matiasa. O Matiji piše i Duišin, ${ }^{28}$ kao i o rogozničkim plemićima (Marušićima...) općenito. O njima piše i

28 "Jedna je grana pl. D. prešla sredinom 16. st. s drugim plemićima Rogoznice, Poljica i Omiša u Pučišće na Braču... Godine 1577. pl. Matija Davidović je gradio jednu od trinaest kula (kaštela) u Pučišću (današnja kula Mičelović) na kojoj se i danas vide inicijali", VIKTOR AnTE conte DuIšin, Heraldički zbornik - Zbornik plemstva, sv. 2, ops. 1, Zagreb, 1939., str. 158. O bračkim Marušićima piše i Dasen Vrsalović u Povijesti Brača. 
grbove oslikava i Carl. G. F. Hayer von Rosenfeld, ${ }^{29}$ a oni se nalaze i u Fojničkom grbovniku i u samostanu kao rukopisi nastali prema Ilirskom grbovniku don Pedre Ohmučevića. Ima ih i u Paškom grbovni$k u$ Miroslava Granića. ${ }^{30} \mathrm{U}$ Listini se, nastavljamo, spominje pučanin Rade Kordijanić u vezi s otkupom, tj. dodjelom samostana i nekim vjenčanjem na kojemu je on bio naveden kao svjedok obojega. ${ }^{31}$

\section{Rogozničke isprave i kronologija}

Od plemićkih potvrda i autonomnih privilegija kronološki navodimo sljedeće, uz komentare u bilješkama.

a) 4. listopada $1289 .{ }^{32}$ povlastice prvi potvrđuje kralj Nemanjić:

Stefan Nemanjić, Božjom milosti kralj Raše, Dalmacije i Bosne itd. Svim banovima, vojvodama... šalje pozdrave i naklonost.

Istaknuti plemići mjesta Rogoznice u Dalmaciji koje je u blizini mora, zvani knezovi Dikličić, Rubraić, Davidović, Blažević, Mikulić, Vojinić $i$ Radić, koji su svi ovamo došli s područja mađarskog kraljevstva

29 C. G. Friedrich Hayer Von Rosenfeld, Der Adel Köenigreich Dalmatien, Nürnberg, 1873. Međutim, piše i nepovezano o šibenskoj Rogoznici i o nekom samostanu u Splitu (Praskvici) u kojemu je navodno bio svećenik Davidović, te da pripadaju ilirskim i staromađarskim plemenima poljičke grofovije. Možda su se miješali, ali poljička su plemena druga priča. Mnogi Davidoviće miješaju i s bosanskim i crnogorskim.

30 Objavio ST krug, Split; grbom, ako je vjerodostojan, Rogozničani (Marušići i dr.) postaju i armalno mletačko plemstvo.

31 "I biše se udal človik u Molstir svetago Joana Jimenem Smolac, a rekli: 'Dohrani me smrti, a moja didina vsa budi v Crkav.' I to jego udanije pohvali knez Miroslav na ta dan i župan Vidoš. I semu udanju Smolca biše svidoci: Desislav, sin Grubenin, i brat jego Radoš od Gmić; Prvoslav; Nemana od Kurosem; Dragota od Splićan; Rade Kordijanić od Rogoznice; Dobrona, Zovidug; Lukaj." "Svidok: braščik Restmir, Petrihna, Rade Kordijanić, Milota Radomirić, Dragota, Vikoj." http://www.knjiznicasupetar.hr/index.php?option=com_ content $\&$ view $=$ article $\& i d=40 \&$ Itemid $=15$ (22. 3. 2019.).

32 Pitanje je raskoraka između godina nastanka povelja i navodne vladavine ranih vladara, pa i ovoga. No nepotrebno i teško je u dubinu medievalistike ući svakomu tko nije povjesničar, a i njima samima, zbog manjka izvora i napose - izvornika. I Qualiter (Pacta conventa, 1102.) uzima se kao falsifikat (npr. prema Šufflayu i ostalima), ali opet samo formalni, a ne i materijalni, tako da se taj termin može, ali se ne bi smio uzeti s averzijom i neutemeljenošću, posebice kad se u obzir uzme razdoblje iz kojega spomenute isprave datiraju. Druga je stvar u tome što je u političkim nadmetanjima ta teza ili činjenica zloupotrebljavana. 
zajedno sobiteljima i zaposjeli to isto mjesto zajedno sa svom svojom imovinom, a od kojih su kasnije potekli mnogi drugi plemići, predstavili su se mojem veličanstvu, po jedan iz svake obitelji, poslani od svoga kneza, vojvode, sudaca i čitavog savjeta da podvrgnu sebe, sinove $i$ čitav svoj narod mojemu veličanstvu pod uvjetom da oni sami u svom savjetu smiju izabrati kneza, vojvodu, suce, javne službenike i da smiju voditi sudske procese $u$ kriminalnim i civilnim parnicama i donositi presude druge naravi prema vlastitim običajima i zakonima. Budući da su oni velikim žarom sudjelovali u ratu zajedno s mojom vojskom protiv mojih neprijatelja... pokazali se hrabri i zakleli biti vjerni... oni nikad ne trebaju plaćati niti meni niti mojim podanicima danak, bilo $u$ razlicitim plodovima, bilo od zarade $u$ bilo kojem gradu $i$ mjestu našega kraljevstva...nego neka budu slobodni i zaštićeni od bilo koje vrste nameta. Ja im, pak, za njihov dost. trud potvrdujem sve zakone, običaje, povlastice i dopuštam im posjedovati lađe za ribarenje. Dalje, moja odluka im dopušta... ne samo trajnom potvrdom, nego $i$ spomenutom plemstvu dopuštam i da sve ono što je odlučio knez, vojvoda, suci ili savjet plemića, treba biti potvrđeno kao da sam ja sam to dosudio. I potvrđujem im sve povlastice koje su im dodijelili preslavni kraljevi Mađarske i sve ono što su posjedovali u prošlim vremenima, $i$ sve to zauvijek. Srebrnim pečatom... 4. listopad 1289. u Prištini. Tajnik Grabljanović (na latinskom). ${ }^{33}$

33 Ivan Kukuljević Sakcinski, Codex Diplomaticus regni... (CD), sv. VI., T. Smičiklas (prir.), JAZU, 1908., str. 673; listina br. 565.

* Na početku dokumenta Smičiklas je naslovio ispravu kao Bajka o nastanku Poljica. Pogrješka je u svakoj riječi. Naime, fabula može biti prevedena i kao priča ili basna, te nije riječ o nastanku, nego potvrdi postojećega stanja. I, konačno, nikako nije riječ o Poljicima jer Rogoznica nikada nije imala (izravne) veze s njima, a kamoli im bila sinonim i potpadala pod njih, osim toga što je preko brda graničila s njima. Ta je pogrješka plod nerazumijevanja, kao i zamjene npr. sa šibenskom Rogoznicom. Nadalje, godina izdanja isprave ulazi u posebno razmatranje, a potpis kralja Nemanjića kao vladara Dalmacije pogrješka je sama za sebe. Naime, spomenuti kralj nije nikada vladao Dalmacijom (samo Zetom), ali je to deklarativno htio pa se tako samoproglasio. Opetovano, sam je sadržaj isprave itekako važan jer potvrđuje sve teze iz Statuta i njegova kasnijega talijanskog (pa hrvatskog) prijevoda: doseljenje spomenutih obitelji, opisana organizacija vlasti, autonomno uređenje i zakonodavstvo te plemstvo mađarskoga kraljevskog origina! Važne su vrste privilegija, kao neplaćanje danka, samostalno suđenje i vladanje, a koje se ponavljaju i zahtijevaju gotovo identično u svim idućim potvrdama i ugovorima. Sličnost je u načelnoj vojnoj pokorenosti preuzvišenima, a razlika kod Venecije i poslije Turske jest jedino u tome da se njima uvijek ili periodično plaćao porez, a plemstvo se više shvaćalo kao aristokracija. 
b) 6. rujna 1310. to čini ban Stjepan Kotromanić:

Ja, Stjepan Kotromanić, po Božjoj volji viši ban Bosne sa svim svojim vojvodama... želim svako dobro.

Moja je volja trajno čuvati svoje podanike sa svim pravima koja im pripadaju po bosanskim kraljevima, zakonima i običajima mjesta iz kojih dolaze moji vjerni podanici. Ima poštovanih vjernih podanika našoj kraljevini u mjestu Rogoznica u primorskoj Dalmaciji - to su plemići Dikličić... Ti plemići, njihovo vijeće, poštovani vojvode i suci poslali su nam plemićko izaslanstvo da nam predstavi časnu ispravu koju su dobili od Stjepana Nemanjića, pokojnog kralja Raše, Dalmacije i Bosne od 4.10.1289. Ponizno nas mole da potvrdimo tu ispravu, da zapovijedimo da je imaju svi poštovati i da se nitko od podanika naše banovine ne usudi povrijediti tu odredbu niti činiti nažao... Dakle, mi potvrdujemo ispravu od dana tog i od samog kralja. Ono što im je kralj odobrio i mi ustupamo - potvrđujemo zakone, sve običaje i prava. Neće morati plaćati ni prinos, ni od poslova... niti će plaćati pristojbe za ispašu - potvrdujemo sve kako stoji u ispravi. I sva prava koja su spomenuti plemići dobili u vrijeme presvijetlih ugarskih kraljeva, mi potvrdujemo zbog usluga i vjernosti koju su nam isti plemići dokazali te što su obećali vjernost i ubuduće. ${ }^{34}$

\section{c) 21. svibnja 1360. kralj i ban Stjepan Tvrtko Kotromanić donosi ispravu:}

Stjepan Tvrtko, po Božjoj volji kralj Raše, Bosne, Primorskih krajeva i Dalmacije. U miru pozdravljamo sve u Kristu vjerne banove... koji

34 Alen Matošević, "Srednjovjekovne latinske povelje", u: Gradivrh, god. II., br. 2, Tuzla, 2005., str. 217.

* Vidi se kontinuitet isprava koje su vezane, a primijetit ćemo kako obje sadržavaju sličnu početnu salutaciju vojvodama, kneževima, serdarima i službenicima. I obje daju iste darovnice i pozivaju se na iste prethodne dokaze. To je ujedno navodno prva od sačuvanih isprava dotičnoga bana. Rogozničani su se iskazivanjem poštovanja "zaduživali" za buduću vjernost vladarima, ali opet, zbog daljine položaja (od gotovo svih), od tih su potvrda imali više koristi radi vlastite legitimacije u matičnoj okolini nego što su činili protuusluge. A to im je i bio glavni interes i mudar diplomatski potez, jednako koliko i nužan, jer se kasnije već primjećuje pokušaj blagog poricanja njihova položaja koji su morali učvrstiti idućim opetovanim potvrdama novih vladara i država. Zbog svega toga, do kraja samostalnog postojanja nikada i ni od koga nisu bili ni osporeni ni pokoreni do kraja. 
sada službuju i ubuduće. S poštovanjem i ponizno predstavio se pred našim veličanstvom cijenjeni glasnik knez Dikličić poslan od vijeća, poštovanog kneza vojvode i nama vjernih sudaca iz Rogoznice... Žale se da neki naši podanici krše prava koja su Rogoznici data od strane kraljeva ugarskih $i$ bosanskih te banova Bosne. Ta se prava očituju u ispravama kralja Nemanjića, moga prethodnika, i Stjepana Kotromanića, višega bana Bosne... Moje veličanstvo ne može trpjeti nepravde koje su počinjene plemićima... Oni traže potvrdu svojih zakona, običaja... vjerni našem veličanstvu i na usluzi. Potvrđujemo im zakone, običaje i prava $i$ to ne samo one od ugarskih kraljeva, nego i ona koja su im dali bosanski banovi i kraljevi. Ove se isprave moraju u svemu poštovati. Ti plemići, još, smiju sami suditi, birati knezove, suce, službenike i nadzornike. Sve što oni presude i kakve god odluke donesu bilo u krivičnim, bilo u građanskim parnicama ima se poštovati kao da smo mi sudili. Oni ne trebaju plaćati nikakve doprinose... ni poreze na voće ni na poslove i zarade. Smiju koristiti lađe. Nitko od naših podanika ni pod kojim uvjetima neka se ne usudi ovome proturječiti!A ako to učini, sav će mu se imetak konfiscirati, on će se prognati iz našeg kraljevstva, a ako se vrati, bit će pogubljen. ${ }^{35}$

d) U međuvremenu 30. svibnja 1315. knez Juraj "Gjuro" Šubić daje povlastice cijeloj Općini omiškoj, a i Rogoznici, te prvi put spominje i Brela:

35 A. Matošević, nav. dj., str. 218.

* Već ova isprava, nadalje, potpuno odgovara rasponu vladavine i autentičnosti. Ponavlja više-manje ista prava, a ovaj bosanski ban i kralj uistinu se i protegnuo Dalmacijom, a i Rašom i Bosnom pa stoga Nemanjića naziva svojim prethodnikom. Za razliku od prošlih isprava, osim salutacije, nazire se već i krnja invokacija (po Božjoj volji i u Kristu) i, za razliku od prošlih, tu ima i - sankcija (oduzimanje imovine, i to cijele, u kraljevu riznicu te prijetnja društvenom i fizičkom eliminacijom). Aprekacije nema, nego samo imperativ, što i odgovara naravi darovnice. Naravno, sama povelja ne daje Rogozničanima jasno konstitutivno pravo na sve što se navodi, nego samo deklarira postojeće ex tunc stanje. I sve to još kao permanentno (zauvijek), načelno bez prekluzije i uvjeta. Ali to djeluje samo za spomenutog vladara, dok drugi može i ne mora potvrditi stare teze, ali ipak su to učinili. Dr. Ivan Balta sačuvane bosanske latinične diplomatičke isprave smatra vrlo važnima za povijest Bosne, a, kako vidimo, možemo slobodno reći, i za povijest Dalmacije, Rogoznice i Hrvatske. Valja primijetiti i to da je knez Dikličić jedini došao na sastanak, ali ovaj put u svojstvu kneza (običnog), a ne kneza vojvode kakav je bio njegov predak i prvodoseljenik Mikloš Dikličić. 
Potvrđujem sve ono što je ranije spomenuto i druga njihova prava $i$ stare slobode koje su imali za vrijeme vladavine kralja Bele i drugih knezova, a koje su obećane pod zakletvom s plemićima... da u naše ime i ime naših nasljednika nikada neće biti prekršene ili osporavane. Želim takoder sve te slobode i povlastice koje s punim pravom uživaju stanovnici Kučića, Svinišća, Rogoznice, Brela i drugi koji su nastanjeni unutar tih granica. Potvrđujem svojim pečatom svjedočanstva svih njih $i$ "trajnu" valjanost dotične isprave. U Klisu.." (na latinskom). ${ }^{36}$

e) 30. ožujka 1437. ponovno hrvatski knez (i to velikaš) Senja, Modruša, Cetine, Klisa, Omiša i Dalmacije te ujedno i ban Hrvatske $A n z ̌$ Ivan Frankopan daje Rogoznici Diplomu o pravima:

Svakom onom koga se ovo naše bude ticalo, obznanjujem, kao što sam obećao i obećavam plemenitim ljudima Rogoznice, svojim podanicima, da ću ih štititi i da ću štititi njihova pripadajuća i stara dobra, zakone i slobode, po kojima su bili naviknuti živjeti, te da na to podsjete svoju braću koja se ili mogu pronaći drugdje ili su drugamo odselila, na njihova nasljedna dobra, na moju poslušnost, staru slobodu i pravnu državu. Isto tako, one koji su ovdje prisutni, na slobodu, pravednost i pravo slobode. I stoga dopuštam ovim pečatom da moja isprava dobije na snazi. U Omišu, a.d.... ${ }^{37}$

f) U vrijeme mletačke vladavine Venecija navodno potvrđuje stare privilegije Rogoznici već 4 . travnja 1423., ${ }^{38}$ a nakon potvrde iz $1680 .{ }^{39}$

36 CD, T. Smičiklas (prir.), sv. VIII., Zagreb, 1910., str. 395.

37 ANDRIJA Kačić Miošić, Razgovor ugodni naroda slovinskoga, Knjižara A. Jakić, Zagreb, 1862. (1756.), str. 376. na latinskom.

38 Ali od toga se ograđujem jer je na taj datum izdana potvrda privilegija $\mathrm{Pa}$ strovčanima, što su možda talijanski autori laički povezali s Rogoznicom i rogozničkim prezimenima (npr. Radić je prezime čiji su nositelji boravili na mnogim različitim područjima, pa i obitelj "Franz von Radića" čiji se grb nalazi u HDA).

39 HR-DAZD-33 Vlada za Dalmaciju, 1802., sv. 167; br. spisa 852, pag. 303. Dikličić i Rubinić traže je u ime svih, kao i Kardišić i Alaburić u drugoj (pag. 309). Na str. 278. nalazi se Nota delle prime famiglie nobili di Rogoznizza. U njoj se opetovano ističe kako su plemići ugarskoga podrijetla (ali kralja Bele, što je djelomično prijeporno) te kako su potvrđivani od mletačkih principa i bana Anža Frankopana. 
i 1690., ${ }^{40}$ glavni providur za Dalmaciju Marin Antonio Cavalli izdaje novu potvrdu 14. srpnja 1740.:

Ja, Marin Antonio Cavalli, za Mletačku Republiku, vrhovni upravitelj u Dalmaciji i Albaniji, ustvrdujem na osnovu ispita i dokaza Ureda grada Brača i Omiša, da sljedeće obitelji potječu iz plemićkih obitelji Rogoznice kuće Rubnić, zvani (detti; rečeni) Knezović, Blažević zvani Kardišić, Dikličić zvani Kuzmanić Boroević, Davidović zvani Marušić, Voineo(ić) zvani Dom Lučić, Mikulić zvani Alaburić i Radić (samo, kasnije i Jerolimović). Također, oni bi po pravu sami mogli razumjeti da su te plemićke obitelji bile javno privilegirane. S ovlašću našeg Zapovjednika i temeljem sadašnjih zakona naređujemo i određujemo, da gore navedene Obitelji ne moraju pripadati političkoj grupaciji zajedno s Vilićima, već se imaju smatrati Plemićkim obiteljima Pokrajine Tonza. Tako bi trebalo biti izvršeno itd. Split, ...1740, M. A. ${ }^{41}$

g) Jedan od posljednjih mletačkih duždeva Paolo Renier, u ime venecijanskoga Senata, donosi i posljednju poimeničnu potvrdu plemićkih statusa obiteljima (nobiles), također u srpnju 1787. godine. Ona se nalazi u privatnim rukama potomaka dr. Filipa Marušića iz Drniša. Upravo $1787 .{ }^{42}$ obrada popisa donosi stanje (ali u građanskoj Hrvatskoj) prema kojemu ukupan broj plemstva sa suprugama i djecom iznosi 25.000 nešto više od 300.000 stanovnika Hrvatske i Slavonije. Od toga je u nekoliko tisuća plemićkih obitelji bilo i 1528 svećenika. Ukupan je postotak bio dakle oko 6,5 \%, a upravo kalničko, turopoljsko i zelinsko plemstvo imaju velik udio. ${ }^{43}$

40 V. A. Duišın, nav. dj., str. 57.

41 Župni ured u Lokvi Rogoznici (oboje), a prijepis u dukalima na talijanskom u: HR-DAZD-1, 53. Marin Antonio Cavalli 1738. - 1741., kut. 1-7, fol. 158v.

* Cavalli iznosi promjenu prezimena od starih iz prošlih isprava u današnja koja postoje u Rogoznici i koja su sukcesivne sljednice prezimena tih, prvotnih obitelji. Ta, nova prezimena pojavljuju se već u ispravama iz 15. stoljeća. Tako nastavljaju i Kačić Miošić i ostali.

42 Te su godine u zadarskom arhivu "indeksirani" i porezni nameti, odnosno kašnjenja za doba generalnog providura Angela Mema (III.) i poslije Angela Dieda (II.), dokumentom pod imenom "...delli nobili di villa di Rogosnizza".

43 Nataša Štefanec, "Plemstvo"

(https://bib.irb.hr/datoteka/630284.Stefanec_-_Plemstvo_u_18_stoljecu_2013.pdf, (13.3. 2019.). 
Bartul Marušić - Diplomatičke isprave Općine Lokva Rogoznica

\section{Dvostrani ugovori}

Prijeći ćemo sada kronološki na važne rogozničke diplomatske isprave koje imaju karakter (dvostranih) ugovora, a ne jednostranih povlastica.

1) - 3. ožujka 1444. Omiš i Rogoznica sklopili su (prvi) ugovor s Venecijom:

Posveta Omiša i Rogoznice

3. ožujak 1444.

Franciscus Foscari iz Venecije i plemeniti vođa milosti Božje, i čovjek Mudrosti Christopharo Marcello po nalogu splitskog grofa i ostalih vladara spomenutog grada i nasljednika odanih u zdravlju i ljubavi.

${ }^{*}$ Pojavivši se u prisustvu Thomasa Pipinicha Omiškog proširili su vlast u četiri poglavlja u zajednici Omiša i Rogoznice, za koje je traženo da ih potvrdimo. Mi smo njihov ured povjerenja, i potvrdujemo zahtjev četiri kapitula s našim konzilijem, i odobravamo ga; Želeći vršiti zapovijedi slobodno, da se tako i pridržava. Tenor illorum talis est.(lat.)

*a Tomaso Pipinich iz Omiša služitelj Vašeg gospodstva ponizno molim u ime naših vjernih seoskih podanika Omiša kao i Mjesta Rogoznice, koji se sviđaju Vašoj Visosti, da mi dodijelite vašu Privilegiju.(tal.)

Kako bi svi naši drevni običaji i zakoni bili podržani, da smo držani $i$ vođeni prema našim običajima, kao što smo bili vođeni od drugih gospodstva koja su nas držala, kao i da potvrdite naše privilegije.

Naš kneževski dvor, dana 3. ožujka $1444 .{ }^{44}$

Već 1475. Rogoznica i cijeli primorski kraj od ušća rijeke Cetine do Neretve pao je pod tursku vlast i bio uključen u Hercegovački sandžakat. Potom su do 1500. godine bili vraćeni i pripojeni Mletačkoj Republici, a od 1500. dalje opet vladaju Osmanlije. U popisu kućedomaćina 1475. - 1477. spominju se imena Rogozničana koji "pripadaju

44 HR-DAZD-33 Vlada za Dalmaciju, 1802., sv. 167; br. spisa 852, Stampa delli nobili di Rogoznizza... "Dedizione Almissa e Rogoznizza...", a original se nalazi(o) u Veneciji pod ...Ducali Palatio die 3. Martii 1444. Ind., VII, DaV. 
vojvodi Dadoju" (bez prezimena): Vukić sin Ivana, Ratko sin Bjelice, Radivoj sin Ratka, Vuk sin Jelice... ${ }^{45}$ U Rogoznici je bilo 16 kućanstava, jednako koliko ih imaju tada i mjesta Kučiće i Brela (18). "Turcima je bilo glavno plaćati poreze", što je razbježane stanovnike ipak privlačilo natrag na njihove obradive površine i ognjišta da rade dalje u poljoprivredi i stočarstvu.

2) - Nakon bitke na Lepantu 4. studenoga $1571 .{ }^{46}$ Rogoznica, primorje i Poljica sklapaju (drugi) ugovor s Mletačkom Republikom u vrijeme sklapanja saveza Svete lige protiv Turaka. ${ }^{47} \mathrm{Za}$ osmanlijske vlasti u Rogoznici i uopće u 17. stoljeću nalazimo mnoge javne isprave, "pritužbe" i korespondencije (mahom s Omišem). Iz Bogišićeva arhiva skupljene su u zbirku Aleksandra Solovjeva, one koje se tiču Rogoznice ili je spominju u kontekstu. Jedna se od njih odnosi i na pitanje sudovanja i nadležnosti između Osmanlija i Mlečana (i posjeda), a u vezi sa sporom Rogozničana i Omišana. ${ }^{48}$ Prema podnescima, Omišani su izgledali napasniji prema Rogoznici i Osmanlijama nego obratno. Drugoga veljače 1641. Marko Vuletić, tadašnji knez Rogoznice, piše providuru omiškom (prije nego što je koju godinu poslije sam aga-dizdar intervenirao za njih), tužeći se zbog toga što Omišani ulaze u njihov hatar (naoružani) i čine štete Rogozničanima. ${ }^{49}$ Unatoč tomu, za nekoliko će godina Rogoznica opet ipak stati

45 Slavko Kovačić, "Iz povijesti župe, sela i kraja - Imena kućedomaćina u selima Kučiće, Rogoznica i Brela u turskom popisu iz god. 1475.-1477.", u: Zov rodnih ognjišta, god. V., br. 2, Župni ured Kučiće, Kučiće, 1999., str. 15-17.

46 Alačević navodi da se već 1561. pokušalo uzaludno sklopiti sporazum, a 1570. ima i kapitul o Poljicima i Rogoznici. HR-DAZD-33 Vlada za Dalmaciju, 1802., sv. 167; br. spisa 852, str. 276, a 1571. HR-DAZD-33 Vlada za Dalmaciju, 1802., sv. 167; br. spisa 852, str. 332 .

47 Grga Novak, Prošlost Dalmacije, knj. 1, Marjan tisak, Split, 2004., str. 169.

48 Al-aga, nazor Makarski, javlja providuru da se Juraj Kuzmanić tuži na Jerolima Križanića:

"... A po tome neka zna V.M. kako dođe k meni Juraj K. iz Rogoznice, tužeći se na Juru Križanića da mu drži vinograd, a on da je carevo blago. Zato tako otiđe u vaš grad, oni veće ne može na carevu krađu držati bašćine. Ako li mu što krivo, neka dođe s ovizim moim čovikom, ja ću sud učiniti i jednom i drugomu. A naši ljudi ne mogu na vaš sud hoditi, a ako bi ko i otišao na vaš sud, sve bih mu uzeo što bi imao", Muksur Alija, ponizni Aga i potpis - gnu providuru da se dade u ruke u Omiš, br. 101/1638.

49 " U svem (vele) prisvitli gne, lubimo ruku vaše prisvitlosti s tizim vele drago pozdravljamo 
na stranu Mletačke Republike i priznati joj vrhovništvo, odnosno "savez". Još 1635./1636., u dokumentima br. 86 i 88, spominje se naplaćivanje dugova (uzdarja) kneza Dorića u Rogoznici za baštinu Zakučca koje je naplaćivao kapetan imotskoga i ljubuškoga Omer-aga. Upućeno je omiškom providuru, a Mus-aga Kapetanović piše dalje o nekom rogozničkom glumcu kojega su u Rogoznici odveli (ili oteli) vojnici Arbanasi. Dana 13. siječnja 1643. pop Ivan Matijašević, kurat (župnik) od Rogoznice, javlja providuru omiškom o slučaju kuge u Zagvozdu:

Prisvitli... ovih dana, to jest ovo treći dan sam sla čovika vašoj prisvitlosti, avizajući da je kuga u Zagvozdu ... Paka smo slali izviditi sve kako će, i tako gne istinom: umrle su dvi žene i jedan čovik, svite pomnu od svih stran, jere smo i mi digli pratiku od onih seli, da ne dohode u selo. Ko prođe ob noć pod selo mi ga ne vidimo, jer je put pod selo. Ako dne od onih selih, mi mu nećemo dati pasati doli. I tako, avizaem vašu prisvitlost istinom je ono što ni umrlo u onoć kući, to bilo je u goru... S ovim dospitkom stojim vazda za služiti vašoj prisvitlosti, u kih u Rogoznici... u ruke plemenite u Omiš. ${ }^{50}$

3) - Zatim 1646. ${ }^{51}$ godine dakle Rogoznica i svi makarsko-primorski knezovi sklapaju (treći) ugovor s Mletačkom Republikom, i to u vrijeme tursko-mletačkoga Kandijskog rata oko otoka Krete. Prema tekstu ugovora koji je objelodanio dr. Nikola Zvonimir Bjelovučić (i

Sa svi tizim... ne moremo živiti od nepravde vaših jednih Omišani, ne dismo od svih. Nego od onih, ki čine nepravo, nečma što je bilo od pri... Učera došli su s puškami u naš konfin alit kotar, I našli su ki beru drva i čelad ki biru divje zele ... pak vazam ona gvozdja kimi su brali neboga čelad drva tako kij su i odnili, ča to ne biše pravo... Odagnali su troje goved i jednu mazgu, čineći pritne i zamećući skandale u našem kotaru. Mi i vaši stariji su vazda bili virni tomu mistu, kako će naći to vaša presvitlost, hoteći lipo živiti... Ako presvitli gne, pokarajte takve vaše mištane za to što su dosad činili... kako je bilo vazda da štetu plati oni ko bude učinija ...

Marko Vuletić sa svimi Rogozničani, na cijelom arku: trag pečata od mrkog voska."

Bogišićeva zbirka omiških isprava..., Aleksandar Solovjev (prir.), Kraljevska akademija, Beograd, 1935., dok. br. 138, str. 208. na srpskoj ćirilici.

50 Ibid, dok. br. 144.

51 HR-DAZD-33 Vlada za Dalmaciju, 1802., sv. 167; br. spisa 852, str. 288. Cijeli je tekst preopsežan da bi se prenio doslovce. 
Andrija Kačić, uz venecijansku Stampu), na čelu svih knezova bio je kučićki knez Marko Srdanović koji je postao glavni "knez od Primorja". ${ }^{52}$ On je korespondirao s mletačkim providurima, iz čega je u izvješćima razvidno kako se na Braču tajno sastaje i pregovara. Primorje kao župa i nahija obuhvaćalo je sva tadašnja mjesta pri makarskom moru i nekoliko u zaleđu bez Omiša (imenom se ne odnosi na današnje sjevernojadransko Primorje) te su zato u ugovoru i potpisi 14 knezova, među kojima se na 12. mjestu nalazi Marko Knezović (prije Rubnić) iz Rogoznice. Ukupno je bilo oko 20 naselja koja su imala oko 5000 stanovnika i od toga "2.200 sposobnih za oružje". Od pregovora se planiralo odustati zbog straha od neuspjeha, nego "kada svi potpisnici budu sigurni barem da će se tomu spremno pridružiti knez Marko Srdanović i velečasni rogoznički svećenik don Ivan $\mathrm{Ne}$ nadić, koje on poznaje kao ljude velike hrabrosti i ugleda..." ${ }^{53}$ Dakle, uza Srdanovića najugledniji Primorac bio je rogoznički župnik čije se mišljenje čekalo u vezi s idejom o savezu s Mletačkom Republikom. Zato je drugi sastanak bio zakazan u Rogoznici, gdje su dvojica "makarskih plemića, župnik glagoljaš Nenadić i neimenovani rogoznički knez tog dana već o sunčevu izlasku... dočekali providura Caotortu i Gelisea. Knez Marko Srdanović nije došao ali je poslao pismo u kojem je posvjedočio svoju spremnost za sudjelovanje u protuturskom pothvatu..." ${ }^{54} \mathrm{U}$ izvješću se nastavlja kako je rogoznički velečasni dužan i voljan i više od ostalih proliti krv kako bi se oslobodili od teškog jarma te "podvrgli Privedroj Republici". Smatra kako će pothvat nedvojbeno uspjeti i Turke zadržati iza planina, ali zimi, a ne ljeti, jer se boji kako neprijatelj može "pregaziti" Cetinu. S druge strane, pop najozbiljnije upozorava na mogućnost odmazde i novih osvajanja Turaka kada se vrate s većom i nenadmašivom silom. Glavni će problem biti, otvoreno naslućuje, u tome što će Mletačka Republika braniti svoje teritorije, a Primorje prepustiti sudbini i neobranjenosti. Cavotorta je na to odgovorio da će Republika navodno sve svoje podanike braniti jednako, kao i Omiš ili Zadar (i samu Veneciju) i da dogovor otpada u slučaju nepouzdavanja. Nenadićev potpis zato nije na ugovoru s Venecijom (nego samo kučićkog župnika Kadića)

52 I tada biše knezom od Primorja svega Marko Srdanović, stoji u svečanom uvodu župne matične knjige 1636. SLAV Ko Kovačıć, "Iz povijesti župe, sela i kraja - Srdanovići...", u: Zov rodnih ognjišta, god. XIV., br. 1, Župni ured Kučiće, Kučiće, 2008., str. 15. i dalje.

$53 \mathrm{Ibid}$, str. 17.

$54 \mathrm{Ibid}$, str. 18. 
i njegovo se zloguko proročanstvo, na žalost, pokazalo i ispravnim. O samom se ugovoru iz 1646., ${ }^{55}$ koji ističe veliku diskreciju u 22 (24) kapitula, ${ }^{56}$ kaže: Sve vlastele oliti nobili primorski otiđoše principu da mu podlože primorje... i potvrdi sva privilegija koja su imali od starine. Knezovi traže od principa zaštitu od neprijatelja, uključujući oružje i olovo, zatim da imaju pravo biti na svojem vlastelinstvu i gospodstvu od starine, da imaju svoju općinu u kojoj oporezuju vinom, ribom i mesom i da se u vlast ne petlja nitko izvan njihove vlastele; da ista vlastela ima pravo imati zbor kad god je njima drago, da providur ne vodi sa sobom kancelara, nego da se služi s onim koji bude izabran od domaćega zbora (to je važna razlika), da se u zboru biraju pomoćnici i suci koji će suditi s providurom i njemu pomagati u suđenju (opet domaći) te prokurator (kamerlingo), ${ }^{57}$ da se u zboru biraju i liječnici, učitelji te suci koji će suditi puku u primorskim selima i davati kaznu do 25 dukata. Nadalje, da je mandat knezova po dvije godine bez mogućnosti reizbora, osim onih koji su od starine dokazani knezovi, da se oni ne mogu silom birati od principa niti da podliježu daćama, a da u zbor ne može biti primljen nitko (makar bio vitez, "kavalir" ili ban) od Mlečana, osim po svojoj gospodskoj volji. I da isti knezovi ne mogu biti osuđeni na kaznu održavanja i vožnje galija (osim u slučaju izdaje principa i dužda, čime implicitno i jedino priznaju vrhovništvo Venecije, ali i uz držanje po venecijanskim zakonima, prema kojima, žele da se njima vlada, ali uz navedene sloboštine). Pozivaju se na poljičke i pastrovičke privilegije, a u slučaju prognanstva od neprijatelja zahtijevaju ista prava i status u bilo kojemu drugom principovu, odnosno venecijanskom gradu i mjestu. U konačnici žele imati povraćene zemlje od Turaka i imati svoje promatrače na vidikovcima.

Nakon što je buna dignuta i Turci u prvom valu protjerani (bez krvi), uslijedila je u jesen iste godine strašna odmazda koja je imala "katastrofalne posljedice" također i za Rogoznicu. Sva sela, kao i Rogoznica, bila su poharana. Rogoznicu posebno navodi, iako bez nadnevka,

55 Nakon njega je u Stampi delli nobili di Rogoznizza zabilježeno mnogo zahtjeva i zapisa o potvrdi ugovornih obveza i iziskivanje deklaracije starih plemićkih povlastica, mahom u uredu na Braču.

56 Piše na starohrvatskom: Zvonimir Nikola BJElovučić, "Ugovor makarskoprimorskih knezova s mletačkom republikom god. 1646.", u: Historijsko-filološki razred JAZU-a, 1907., str. 319.

57 Po tom je funkcionaru nazvan npr. i zid "Kamerlengo" u Trogiru i ostalim dalmatinskim mjestima. 
Franjo Difnik u Povijesti Kandijskog rata u Dalmaciji. ${ }^{58}$ Srdanovićev je brat smrtno stradao zbog pokušaja povratka turskim vlastima i pregovaranja u Makarskoj, nakon čega ga je providur Cocco okovao u lance na galiji i poslao "Foscolu". Već 1669. mirom između Mlečana i Turaka Makarska s primorjem napokon faktično pripada Mletačkoj Republici. Nakon Kandijskoga, u Prvome morejskom ratu od 1684. do 1699. Mletačka je Republika sela Kučiće, Rogoznicu i Brela isključila iz upravne jedinice Primorja s Makarskom ("turskim" uporištem), nadzirući ih od tada preko omiškoga providura i tek odonda župa zastalno više nije na popisu osmanlijskih teritorija. Međutim, dala im je Venecija povlasticu apsolutnoga vlasništva i posjeda nad zemljom i napokon oslobođenje od plaćanja državne desetine, ali to samo mjestima u priobalju od Baćine do Rogoznice (a ne i u Gornjim Brelima, Slimenu, Kučićima i Svinišćima), čime se opet uočava drukčiji i povlašteniji status, a isto se očituje i u kasnijim potvrdama plemstva. Glavni je razlog bio i mnogo doseljenika u prekobrdskim krajevima, gdje se izvorno plemstvo počelo gubiti, iako su i u Rogoznici nova prezimena pokatkad preuzimala aristokratsku moć, a neka plemena iščezavala (poput Vojnića, Radića...). Venecija, vidimo, "vlada" idućih godina (i potvrđuje stare povlastice), a pred kraj vladavine u Dalmaciji, zabilježena je opća pošast gladi u njoj. ${ }^{59}$ Tako glad nije zaobišla ni Rogoznicu i poharala ju je 1783. i 1784. godine. Zupnik Pava Marušić na zadnjoj stranici župne knjige potresno svjedoči o rogozničkoj krizi, možda najvećoj nakon turske odmazde u Kandijskom ratu, koja je dovela do smrti i (djelomičnoga) raseljenja. Ona vjerojatno prvi put objašnjava i današnju pojavnost (rogozničkih) Marušića u okolnim mjestima u zaleđu (Svinišće, Podgrađe, Omiš, Katuni...). A možda čak i u Širokom Brijegu, kao i postojanje drugih obitelji i prezimena iz Lokve. Zanimljivo je da je već one iduće godine bilo rodno i bogato prinosima:

(U transkripciji) 1783. maja na 3. poče glad kud godir se čuje. Ovde u Rogoznici umri čeljadi velike i mali od glada 43! Ovo vrime 'šenica konta Makarska po libar 70. I taki glad da malo ko osta. Ko ne umri, oni se razbježe po svitu. Otide Ive Ivanko s troje dice u Cesarovinu $i$ Augustin Kuzmanić odvede ženu Katu ... i L. Peraković ženu Jelu...,

58 Vidjeti: Franjo Difnik, Povijest Kandijskog rata u Dalmaciji, Split, 1986., str. 106.

59 Opširnije: Grga Novak, Prošlost Dalmacije, Marjan, Split, 1944. 
ja, don Pava Marušić, kurat od ovoga sela, pisa pravo. Ako budeš titi, neka me se spomene duše $!^{160}$

\section{Zaključno}

Prije 16. stoljeća nisu sačuvani izvori ni knjige pa se malo zna o životnim prilikama u srednjem vijeku i o provođenju zakona koji bi bili od neizmjerne vrijednosti. Rogoznica je kratko zadržala samostalni status u vrijeme prve austrijske dominacije i vladavine nakon pada Mletačke Republike 1797. (kada je pala i slična aristokratska republika Genova s duždom na čelu). Austrija nije donijela neke novìne ni "za" ni "protiv" "pokrajina".61 "Posljedično, Poljičani i mještani Rogoznice mogli su nastaviti uživati u pravu glasa i smatrati se - blaženima u središtu uništenja koje je plemićkoj kasti prijetilo već Francuskom revolucijom u mnogim europskim zemljama, uključujući teritorij bivše Mletačke Republike."62 Međutim, Francuska revolucija pa nadolazeća najezda u Dalmaciju bila je prijelomna prijetnja za opstanak. Jedan očajnički potez i nepromišljena odluka Poljica osudila je obje "republike" na propast. Naivno su, naime, očekivali da će iskoristiti pojavu ruskih trupa u blizini njihova teritorija kako bi dignuli ustanak i podignuli zastavu pobune uz njihovu pomoć, te su 6. lipnja 1807. napali iz zasjede francuski vojni konvoj kod Duća koji se kretao iz Splita prema Omišu. Pritom je ubijeno petero osoba i otvoreno ne-

60 Matična knjiga rođenih 1632.-1833., Nadbiskupski arhiv u Splitu, zadnja stranica.

* Za spomenutog kurata (kapelan pa župnik), koji je došao nakon Petra Kuzmanića, na nekim mjestima piše samo Marušić, a na nekima DavidovićMarušić ili križa prezime, upravo indikativno u vrijeme objave Razgovora ugodnog naroda slovinskoga. Naime, stvarna promjena prezimena ne može se točno datirati niti, na žalost, pronaći u starijim ispravama u kojima bi se vidjeli promjena i prelazak s jednoga prezimena na drugo, kakvi su očito bili česti, a čak, vidimo, povremeno i reverzibilni.

61 Iako je bilo previranja Poljičana s austrijskim vojvodom Thurnom koji je Poljicama htio donijeti novi ustav kojim bi de facto potpuno minorizirao bivše povlastice i gotovo ukinuo neovisnost. Ipak je zbog rata s Francuskom popustio pa je donesen neki novi, malčice nejasni, ali ne radikalni zaokret u ustavnom poretku. Više o tome: Miroslav Pera, Poljički statut, Književni krug ST, Split, 1988.

62 Valentino Lago, Memorie sulla Dalmazia, vol. II., part. 3, Grimaldo, Venezia, 1870., str. 190. 
prijateljstvo između Poljičana i francuske vlade..$^{63}$ Ishod već u samom startu nije bio u skladu s njihovim očekivanjima te su zaskočeni i odmah pokoreni s pomoću vatrenoga oružja, a samo tri dana od početka pobune vrhovni francuski upravitelj u Dalmaciji Dandolo donio je 10. lipnja iste godine proglas pod brojem $826^{64}$ kojim je ukinuo sve osobne privilegije, upravne i stvarne, koje su do tada uživali mještani Poljica i Rogoznice (iako se u udžbenicima spominju samo Poljica). I podijelio je teritorij na tri jurisdikcijska kantona koji su bili podređeni spomenutim vlastima. ${ }^{65}$ "Sela Poljice nisu više politički neovisna. Aristokratska Rogoznica, koja je svojim položajem uzdignuta i ponosna, uzdiše cijeli dan jer je izgubila povlasticu da potjera batinama puk koji manje cijeni sastanke njegova plemstva." ${ }^{16} \mathrm{U}$ drugoj vladavini, Austrija opet nije mijenjala postojeće stanje, ali ovaj put potvrđuje već utvrđenu neautonomiju Poljica i Rogoznice. Negativno stajalište prema hrvatskome plemstvu imala je u startu i Kraljevina SHS, odnosno Jugoslavija, ${ }^{67}$ "koja ga je oslabila na gospodarskom planu putem selektivno provođene agrarne reforme te donekle dalje marginalizirala na gospodarskom planu kao pristalicu prethodne di-

63 U Namjesničkom arhivu iz Garagninova izvješća razabire se kako su Rusi preko omiških izaslanika prijetili da će napasti i razoriti grad. Francuska se bojna zato povukla i prolazila kroz Rogoznicu prema Makarskoj, gdje je "vojni", odnosno fizički otpor bio takav da su pod bajunetama i oružjem život izgubila četiri čovjeka koji su "ostali mrtvi u borbi prsa o prsa". Tom je prigodom jedan harambaša Baučić "počinio nedjelo zakopavši živa jednog francuskog vojnika zajedno sa još jednim mrtvim". Tada je došao harambaša Petar Mimica, rečeni Tafra iz sela Svinišće, sa svojom obitelji kako bi spasio život mladiću, no nakon što ga je istrgnuo iz ralja smrti, sam je poginuo od "suborca". Vidjeti: Tulio Erber, Poljička knežija, prijevod J. Matijević, Priko, Omiš, 2010., str. 102.

64 HR-DAZD-59 opć. 1807., br. 500, svež. 2-4, odneseno iz spisa.

65 "Pod austrijskom vlašću, koja je potkraj 18. st. zamijenila mletačku, nije bilo pokušaja izuzeća dviju republika. Nakon što je zauzela zemlju, francuska je vlast prvo prema njima učinila isto. No 1807. godine, nakon ustanka, carski je providur Dandolo proglasio ukinuće svih osobnih i administrativnih povlastica Poljica i Rogoznice te je njihov teritorij bio pripojen kantonalnoj jurisdikciji Splita, Sinja i Omiša (do Jugoslavije i danas). Od toga razdoblja te dvije 'tvrđave' više nisu imale svoju samostalnost." "Revue de droit international - et de legislation comparee", Tome XXV., No. 1, 1893., str. 477.

66 Ibid.

67 Čl. 4. Ustava Kraljevine Jugoslavije 1931. ("oktroiranog"): "... ne priznaje se plemstvo, ni titule, niti ikakva preimućstva po rođenju". 
nastije, ali ona barem nije fizički atakirala na njega". ${ }^{68}$ Nadalje, u jugoslavenskoj socijalističkoj federaciji već potpuno utišano plemstvo (ponajprije stoga što je bilo feudalno) uključeno je zajedno s drugim društvenim segmentima u redove eventualnoga kontrarevolucionarnog "klasnog neprijatelja" i progonjeno zajedno s ostalima bez posebnog dokazivanja povijesne krivnje. Arhiv francuske vladavine u Zadru $^{69}$ donosi popis stanovništva po kućama $1806 .{ }^{70}$...Iz kuća Bože (Natale) i Petra (Pietro) Marušića osniva se današnje mjesto Marušići (do 1945. zvano Dubočaj), kamo su se oni prvi odselili i proširili se iz Rogoznice, a drugi su Marušići otišli i u Omiš. Dok 1807. Dandolo dakle konačno ukida i samostalnu Rogoznicu, te je godine izvedena i velika pljačka nepoznatih gusara kod Rogoznice na moru. ${ }^{71}$ Tijekom povijesti ona je ipak, pokazali smo, opstala i dokazala kako opstati u krizama progonstva, gladi i bolesti te ratova i promjena okruženja i režima, unatoč manjem teritoriju od Poljica ili Dubrovnika. A time je zadržala i svoj iskonski hrvatski identitet u rijetko viđenoj dalmatinskoj autonomiji.

68 D. KARbić, "Plemstvo - definicija, vrste, uloga", str. 12

69 Nadbiskupski arhiv u Splitu, izdvojeno.

70 Francusko vojno novačenje sela provedeno je 28. 8. 1805., pa tako i Rogozničana, kada je 21 muškarac "uzet", a 4 su oslobođena. To je bilo prije zajedničke poljičke pobune, a u to se vrijeme gradio i "Napoleonov" potplaninski put kroz rogoznički kraj.

71 Vidjeti u: Pomorski zbornik, Opseg 2, str. 520. 


\section{Diplomatic documents of the Municipality of Lokva Rogoznica}

\section{Summary}

Lokva Rogoznica in Central Dalmatia was an independent municipality from its establishment at the beginning of the $13^{\text {th }}$ till the beginning of the $19^{\text {th }}$ century. This municipality had the characteristics of noble republic from its establishment until the period of Venetian rule, and from that period it evolved even to the status of semi-sovereign republic under patronage. This place, though smaller than the neighboring principality of Poljica and the town of Omis, too often neglected in legal and general historiography, had very strong influence on the history of the coastal territory from Omis to Makarska. It was often the border between Eastern Islamic and Western Christian rule. In these turmoil through the wars, Lokva Rogoznica made many important legal-historical and international agreements with the Venetian Republic, which determined its future status and which were supported by many decrees of the Venetian Doge on the confirmation of noble privileges and status. It had also one of the leading and crucial roles in the policy of Primorje toward the Ottomans, Venice and other powers. However, its most important document is the statute in two parts, written in 1235 and 1236. That is one of the oldest Dalmatian laws in the developed Middle Ages and at the very beginning of Dalmatian statutory law. After a rich history, Rogoznica survived despite all the challenges and in the last two centuries it was included in the municipality of Omis and in the Republic of Croatia. The article deals with historical chronology and important legal documents and the most important diplomatic documents are published for the first time in one place.

Keywords: Lokva Rogoznica in the Middle Ages and Herzegovina sandzak; noble municipalities of Primorje; history and law of Central Dalmatia; Rogoznica Statutes. 
Bartul Marušić - Diplomatičke isprave Općine Lokva Rogoznica

\section{PRILOZI}

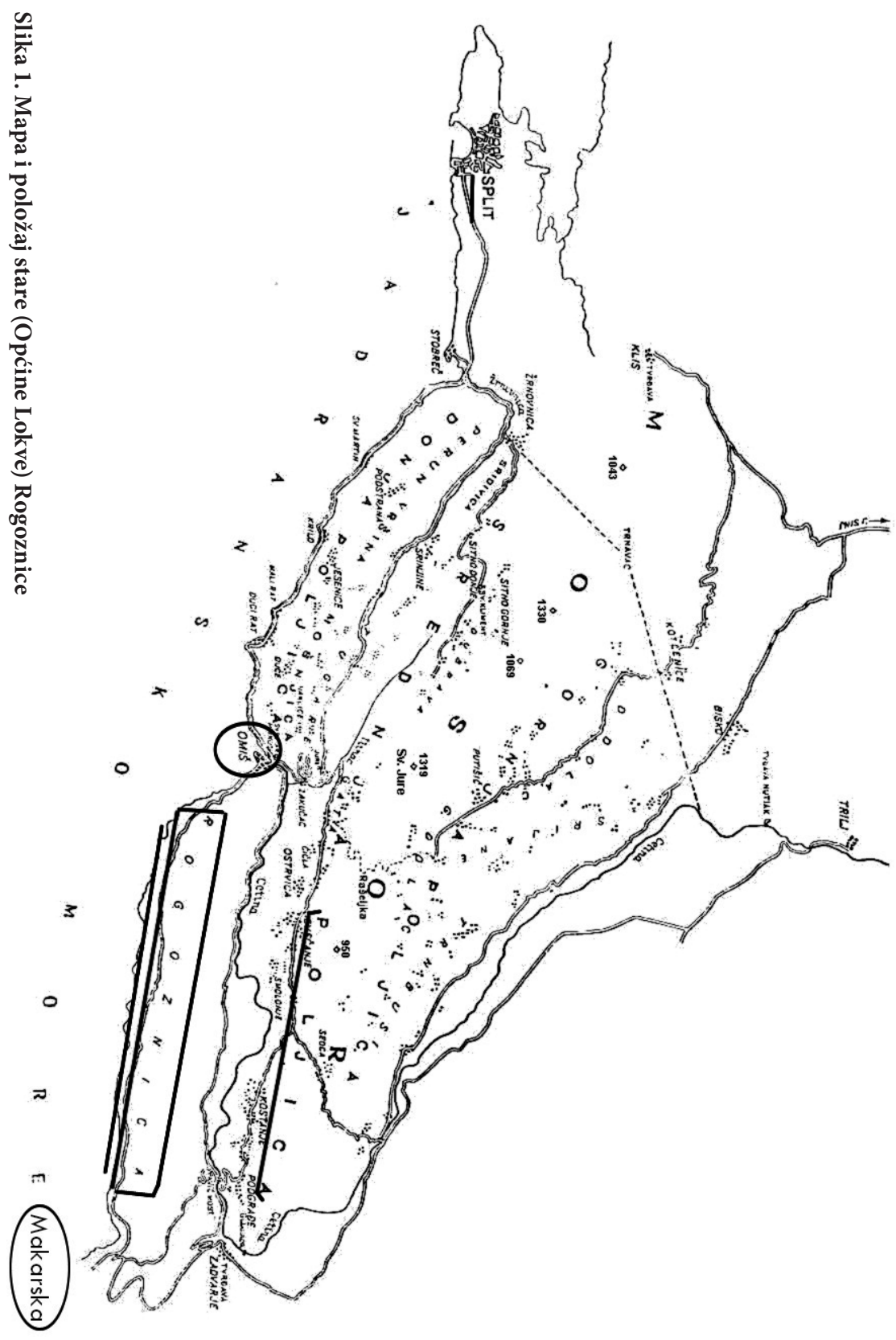


Hercegovina - 5 - 2019., str. 79-114

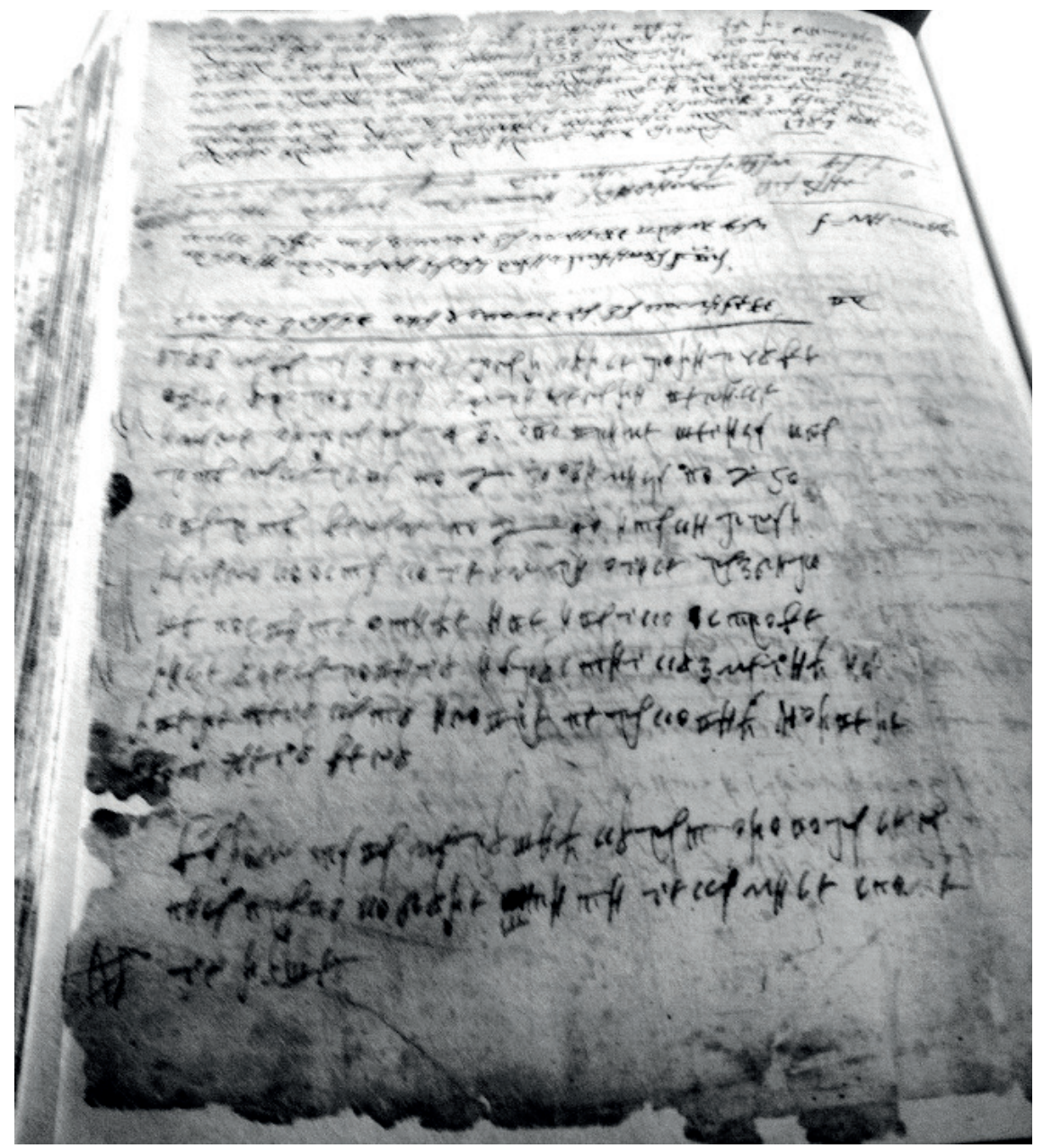

Slika 2. Zadnja stranica Matične knjige rođenih 17. - 19. stoljeće iz Nadbiskupskoga arhiva u Splitu - 1783. "godina gladi"; tragičan zapis župnika o smrti i raseljenju stotinjak mještana (na bosančici) 


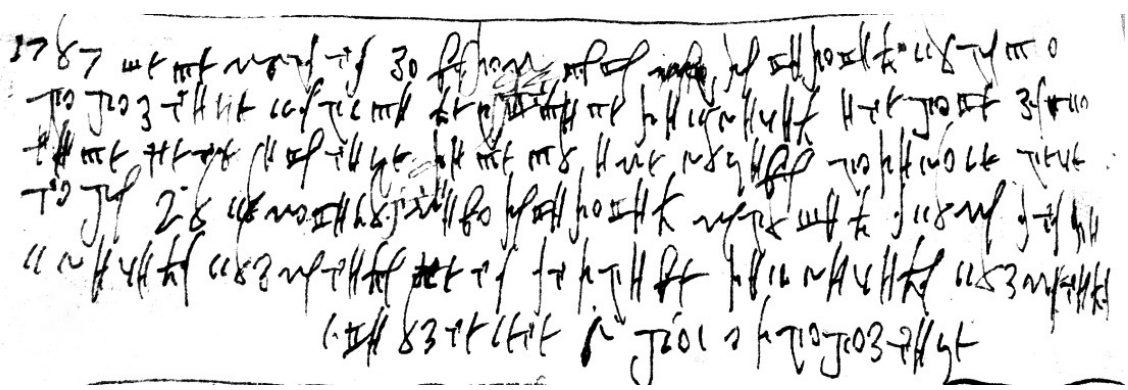

Slika 3. Pop Pava Marušić 1787. zapisuje crkveni događaj u župnu knjigu i potpisuje se najprije s Marušić, a potom ispravlja prezime u staro Davidović (- Marušić) prema Kačićevu djelu i potvrdi plemstva od mletačkoga Senata i dužda iz iste godine.

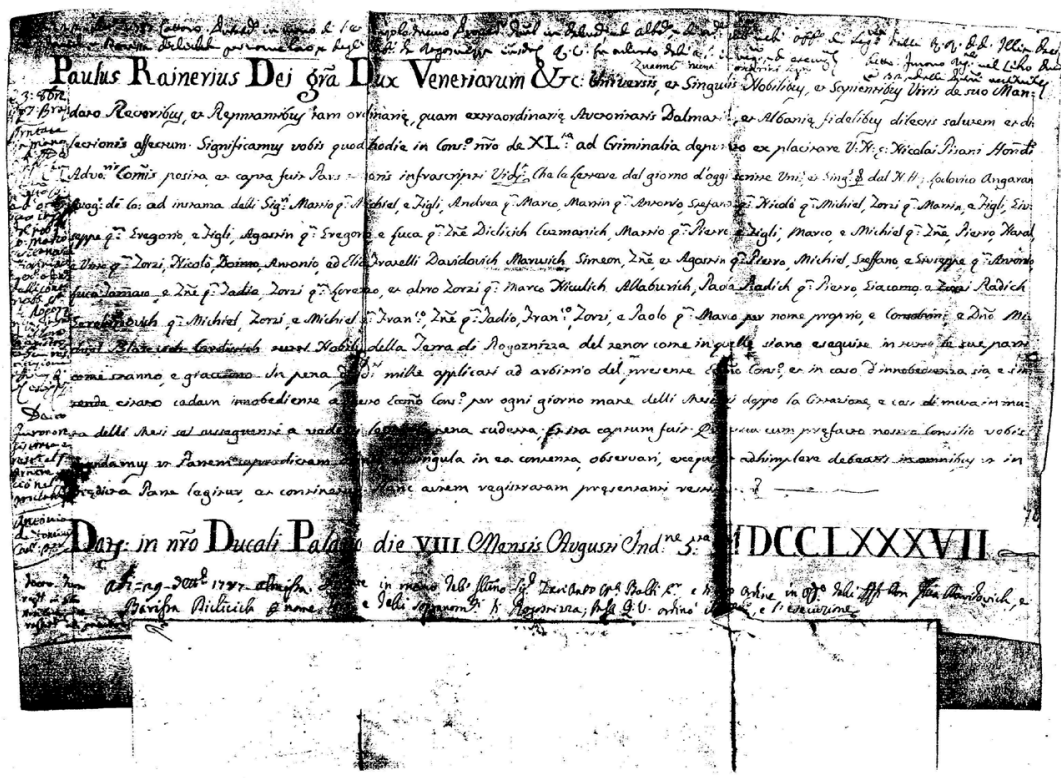

Slika 4. Preslika originalne potvrde plemstva rogozničkim obiteljima koju su dobili od venecijanskoga dužda Paola Reniera 1787. (čuva se kod potomaka Filipa pl. Marušića i na mrežnim stranicama Hrvatskoga plemićkog zbora) 


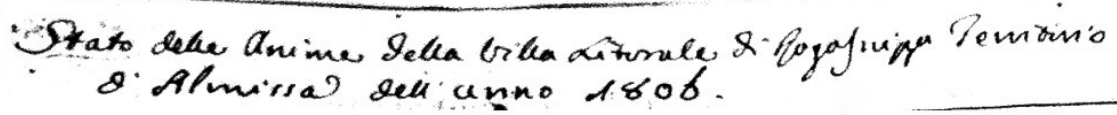

Slika 5. Naslov francuskoga popisa kućanstva iz 1806. pohranjenoga u Nadbiskupskom arhivu u Splitu

POPTS OSOBA

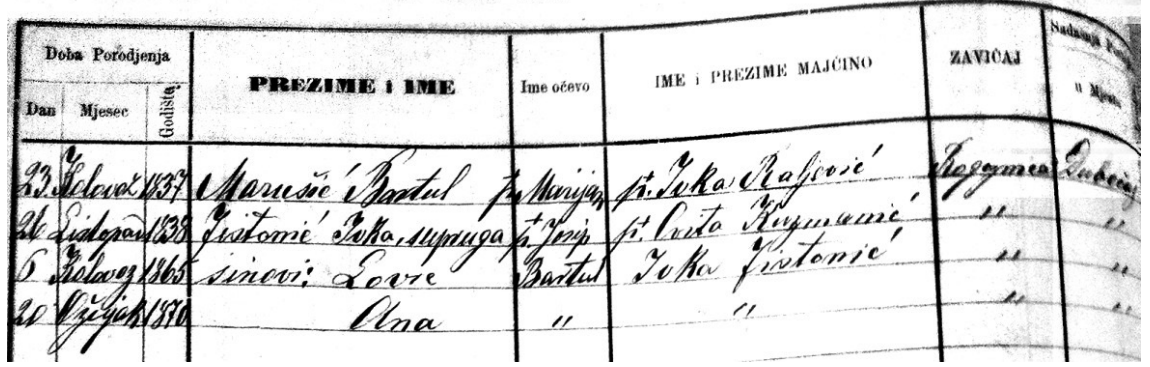

Slika 6. Uvid u župnu knjigu iz 19. stoljeća - međusobno ženidbeno sjedinjavanje izvornih rogozničkih plemena (prezimena) 
Bartul Marušić - Diplomatičke isprave Općine Lokva Rogoznica

Slika 7. Jedan od listova opsežnoga sveska za vrijeme austrijske vlade za Dalmaciju iz 1802. pohranjenoga u DAZD-u i vezanoga za problematiku rogozničkoga plemstva

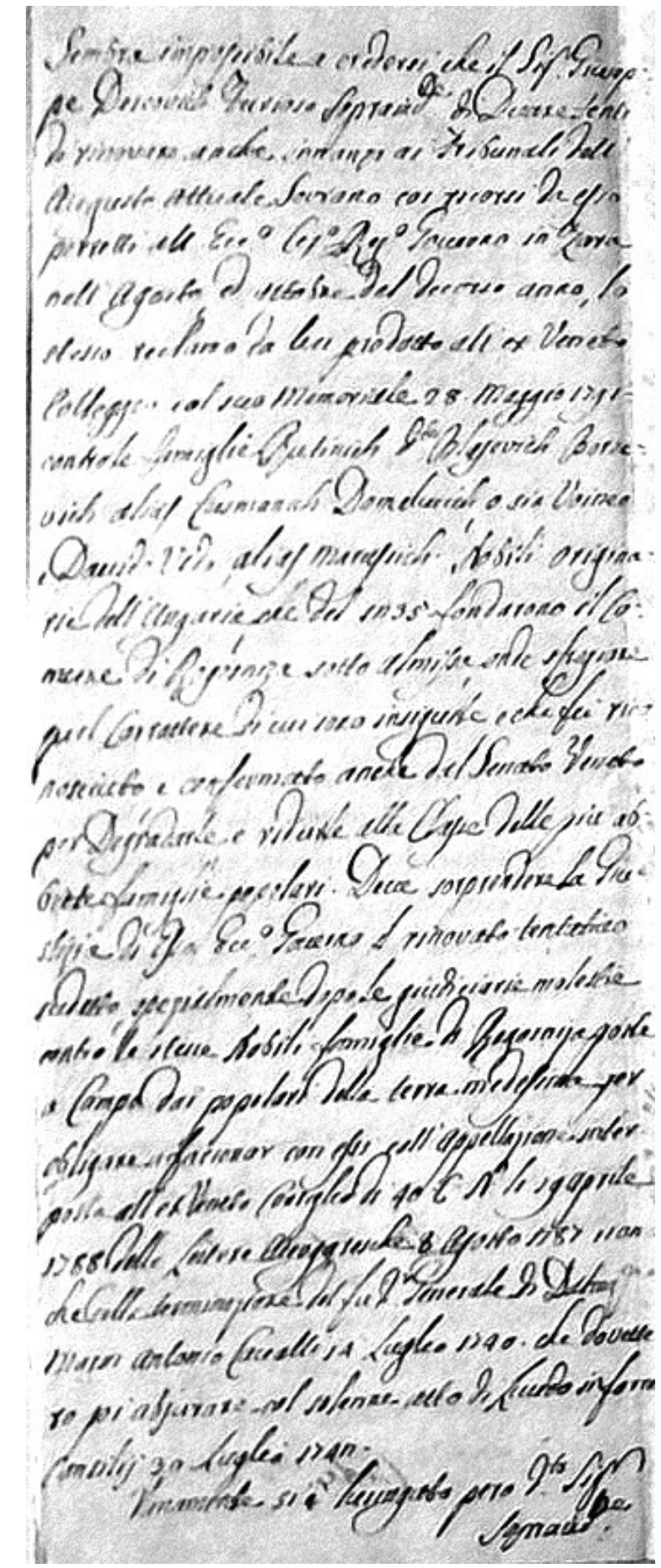

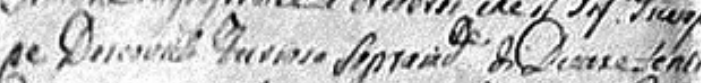

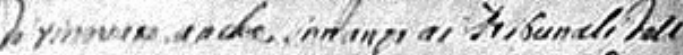

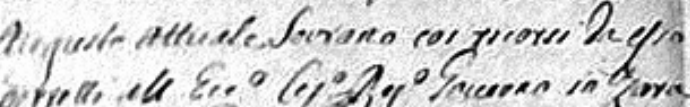

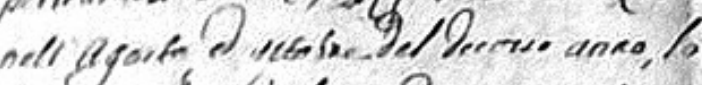

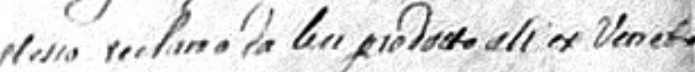

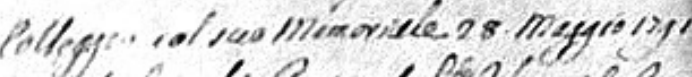

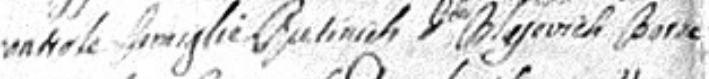

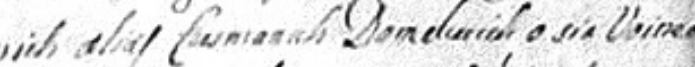

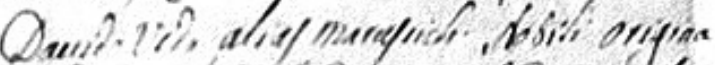

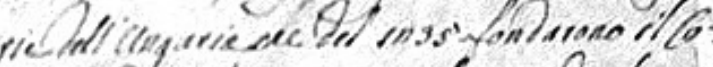

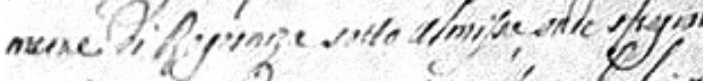

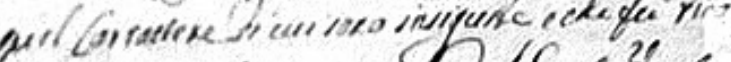

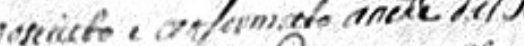

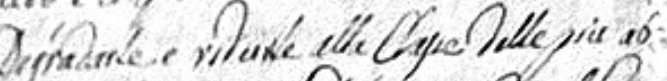

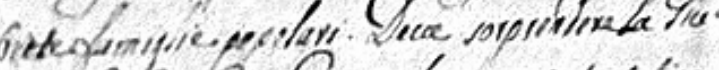

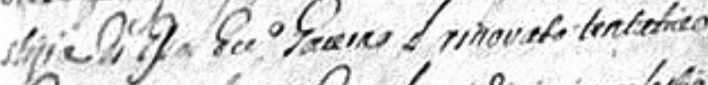

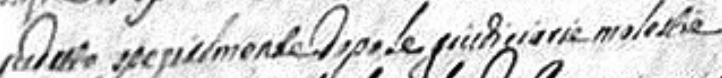

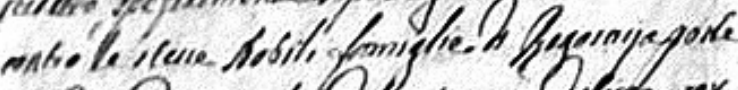

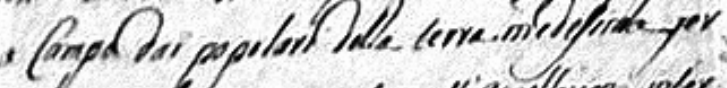

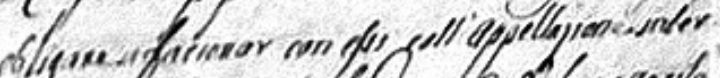

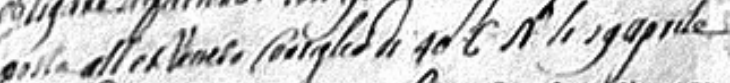

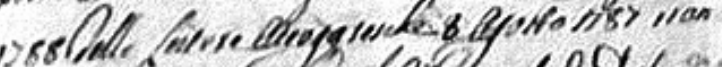

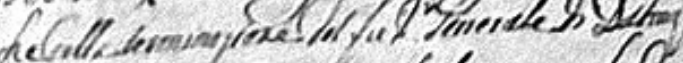

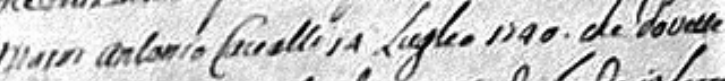

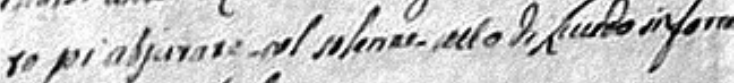
cmaligiga luglei istin. 


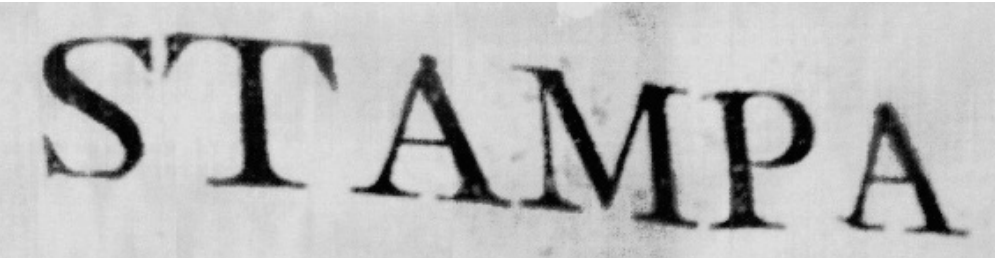

\section{Delli Nubili di Rogoznizza}

C O N T R O

Conforti Popolari

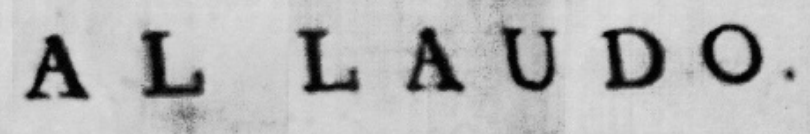

Slika 8. Naslovnica iz venecijanske "štampe" s kraja 18. stoljeća o najvažnijim rogozničkim dokumentima i plemstvu

\section{Altre Leggi di Rogoznizza.} 1236. 7. Febraro.

\section{In Gorizza detta Rogoznizza.} $\mathrm{P}_{\text {Co: Ordinc de'Spp. Sig. Miklos Diklicich }}$ Uladmiro Btaxevich Giudiei fu convocato quento $S_{p}$. Coureglio de Nobili, in cui moftrarono if medemi Comandmenti. che tutte cole, che fi contengono nella foprafcrits Legge fono Rate efeguite, e fedelerentefino la fine operate, e perciô aueito Confeqlo lando e ennferma. 


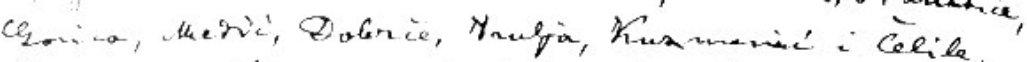

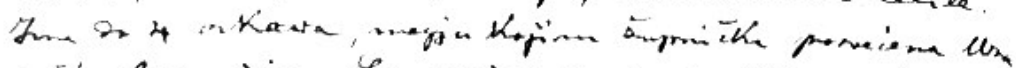

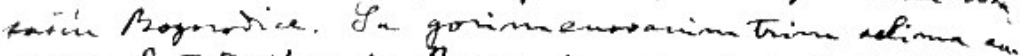

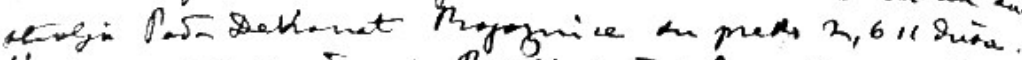

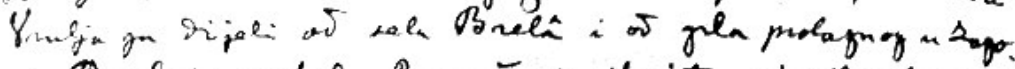

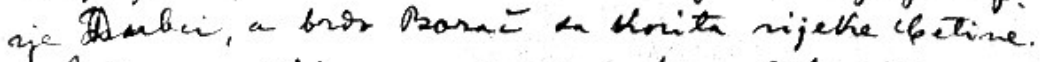

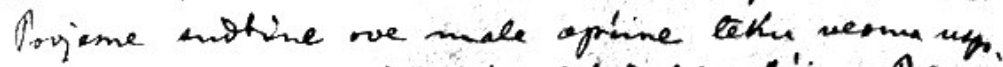

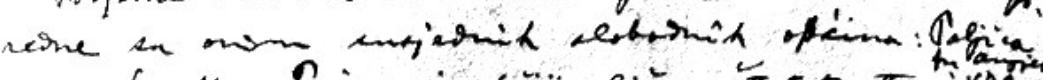

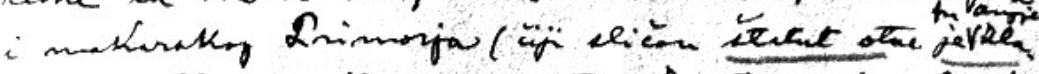

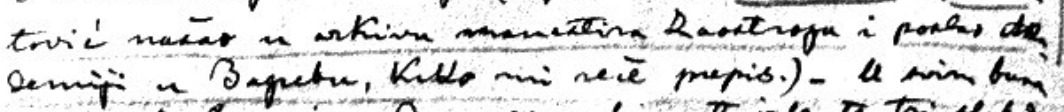

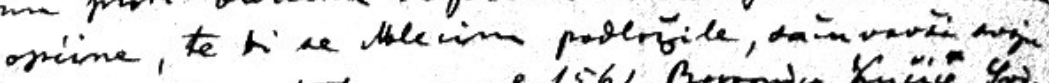

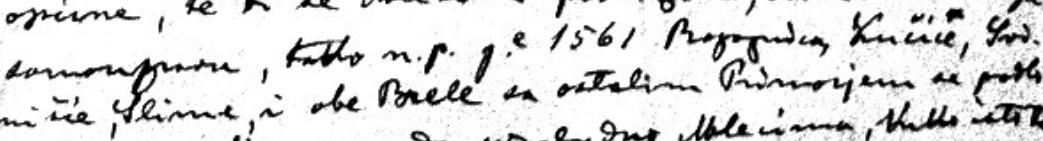

$$
\begin{aligned}
& \text { 1. To ponorise porine Quet Karmje ti } 15 \% l \text {. }
\end{aligned}
$$

Slika 10. Preslika Alačevićeva spisa iz Bogišićeva arhiva u Cavtatu u kojemu se poziva na Zlatovićevo otkriće Statuta makarskoga primorja kao trećeg, uz Rogoznicu i Poljica

Slika 11. Grb rogozničkoga pl. roda (Davidovići - Marušići). Izvori: Wikipedia $i$ Ilirski grbovnik

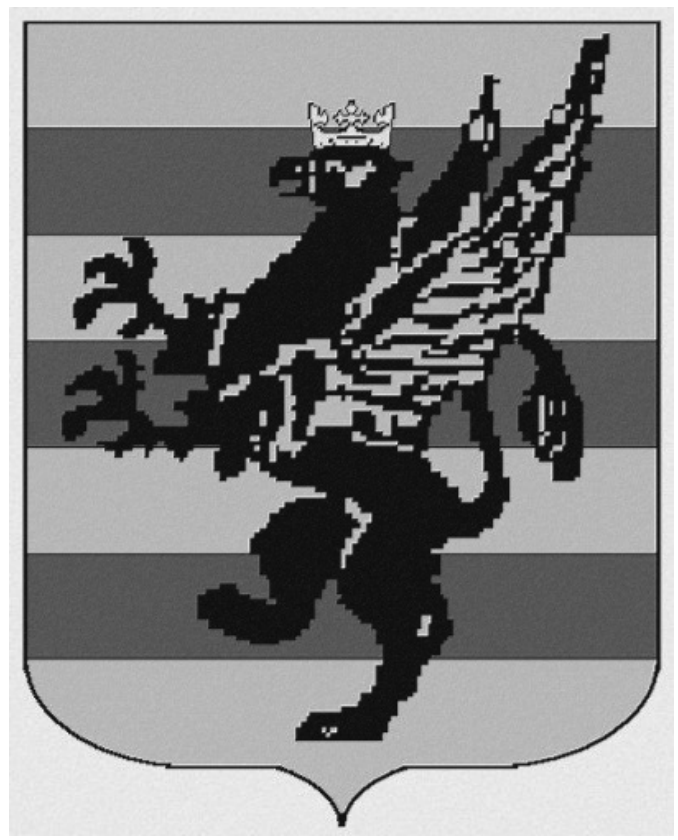


Hercegovina - 5 - 2019., str. 79-114

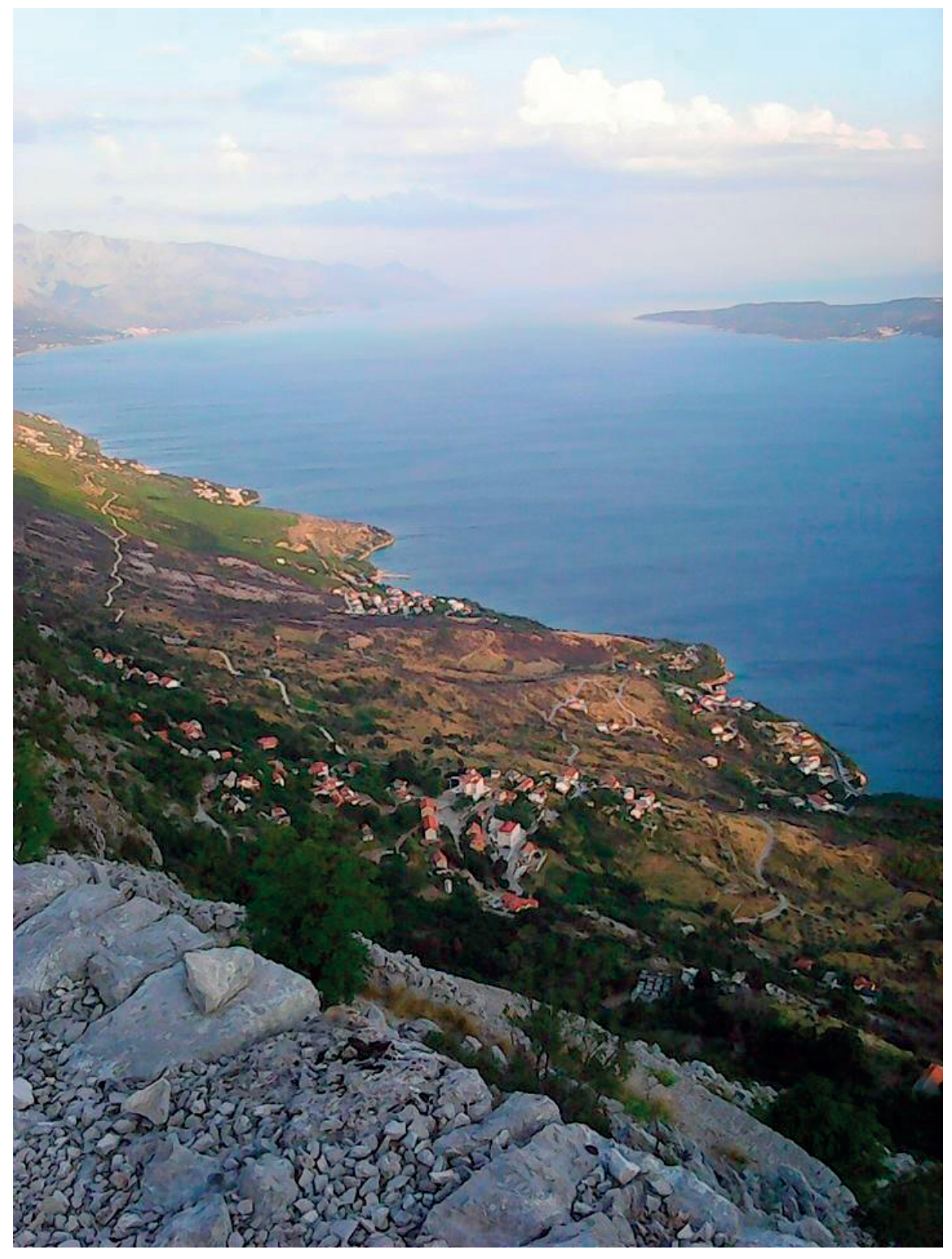

Slika a) 
Bartul Marušić - Diplomatičke isprave Općine Lokva Rogoznica

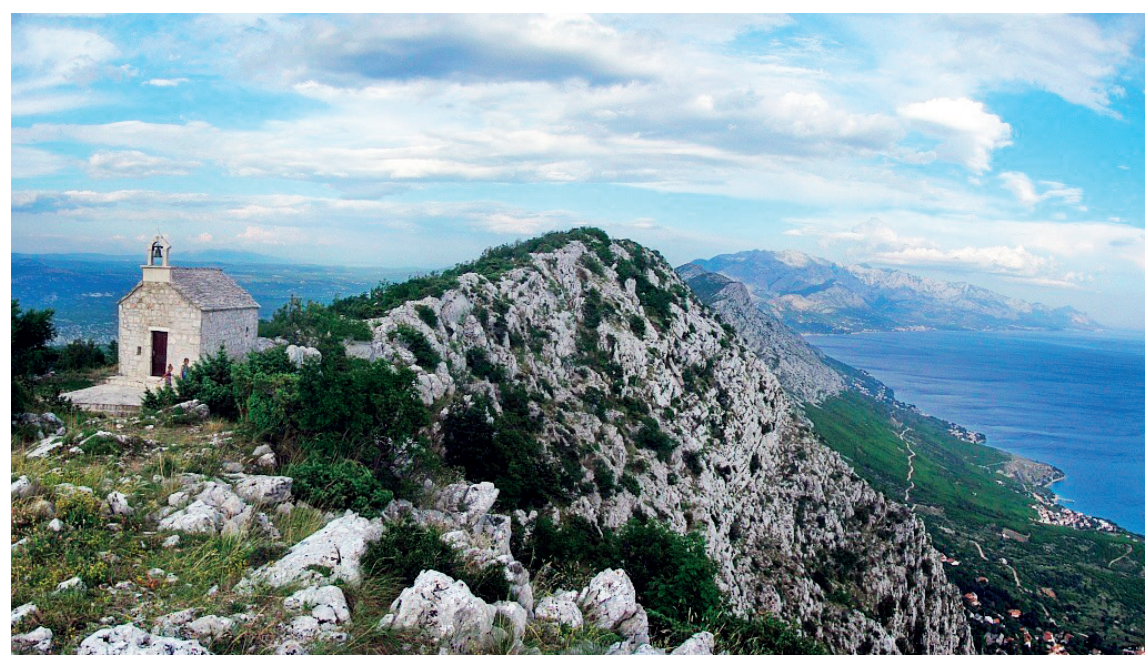

Slika b)

Slika 12. Pogled na "republiku" Lokvu Rogoznicu iz zraka (sl. a), točnije, s planinskoga vrha mosorskih ogranaka, gdje se nalazi i crkvica sv. Vida (sl. b), odakle se vide i Poljica i Makarska (Biokovo) s primorjem te Omiš i otoci (autor) 